\title{
An Investigation of Factors Affecting Willingness to 'Introduce the Elephant in the Room'
}

\author{
Mackenzie Michael Festa
}

Follow this and additional works at: https://researchrepository.wvu.edu/etd

\section{Recommended Citation}

Festa, Mackenzie Michael, "An Investigation of Factors Affecting Willingness to 'Introduce the Elephant in the Room"' (2017). Graduate Theses, Dissertations, and Problem Reports. 5595.

https://researchrepository.wvu.edu/etd/5595

This Dissertation is protected by copyright and/or related rights. It has been brought to you by the The Research Repository @ WVU with permission from the rights-holder(s). You are free to use this Dissertation in any way that is permitted by the copyright and related rights legislation that applies to your use. For other uses you must obtain permission from the rights-holder(s) directly, unless additional rights are indicated by a Creative Commons license in the record and/ or on the work itself. This Dissertation has been accepted for inclusion in WVU Graduate Theses, Dissertations, and Problem Reports collection by an authorized administrator of The Research Repository @ WVU.

For more information, please contact researchrepository@mail.wvu.edu. 


\title{
AN INVESTIGATION OF FACTORS AFFECTING WILLINGNESS TO 'INTRODUCE THE ELEPHANT IN THE ROOM'
}

\author{
Mackenzie Michael Festa \\ Dissertation submitted \\ to the College of Business and Economics \\ at West Virginia University \\ in partial fulfillment of the requirements for the degree of \\ Doctor of Philosophy in \\ Business Administration \\ Concentration in Accounting
Barbara Apostolou, Ph.D., Chair
Naomi E. Boyd, Ph.D.
Jack W. Dorminey, Ph.D. Ludwig Christian Schaupp, Ph.D. \\ Department of Accounting \\ Morgantown, West Virginia \\ 2017
}

Keywords: Abusive supervision, mentoring, public accounting, voicing.

Copyright 2017 Mackenzie M. Festa 


\section{ABSTRACT \\ AN INVESTIGATION OF FACTORS AFFECTING WILLINGNESS TO 'INTRODUCE THE ELEPHANT IN THE ROOM'}

\section{Mackenzie Michael Festa}

One way of maintaining the quality of an accounting firm's practice is for its professionals to speak up when violation of policies and procedures is perceived or observed. Accounting firms operate as a high performance workplace, which can produce an abusive supervisory environment. I employ a quasi-experimental methodology to explore how accountants respond to a violation of policies and procedures when an abusive supervisor is present. I examine how the presence of a mentoring relationship independent of the supervisory assignment influences the protégé's willingness to voice a perceived violation. The findings indicate that abusive supervisory behaviors suppress voicing behaviors of professionals. However, the mentor relationship does not influence voicing intentions in this case. Additionally, the mentor relationship does not moderate the abusive supervision voicing relationship. I contribute to both the accounting, management, and psychology literatures by demonstrating that abusive supervision lowers voicing, which can compromise quality in an accounting context. 
To Mum \& Dad 


\section{ACKNOWLEDGEMENTS}

This dissertation would not be possible without the sincere help and guidance from my committee members: Professors Barabara Apostolou (chair), Naomi Boyd, Jack Dorminey, and Christian Schaupp. Your patience with me was nearly unprecedented.

Commander Anna Hickey, Megan Jones, and Kevin Knotts, I will never be able to adequately put into words how thankful I am for the three of you. You kept me sane, which was no small task.

To my family, you kept me grounded every step of the way. You never let me lose sight of the most important aspects of life. This process was bearable because of you.

Finally, to Justine, I am forever grateful for your sacrifices throughout this long ordeal. Your endless support is astounding. 


\section{AN INVESTIGATION OF FACTORS AFFECTING WILLINGNESS TO 'INTRODUCE THE ELEPHANT IN THE ROOM'}

\section{TABLE OF CONTENTS}

1. Introduction

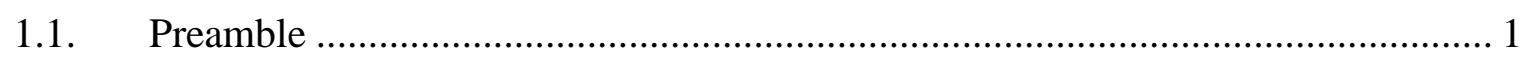

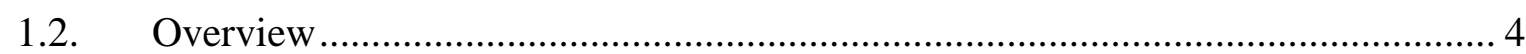

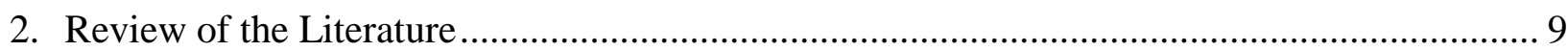

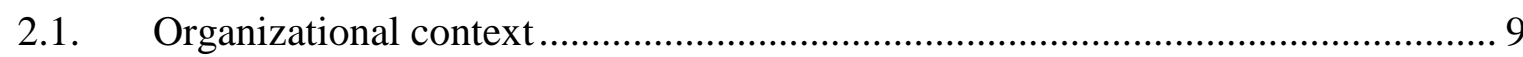

2.1.1. Benchmarking CPA firm practice quality .......................................................... 11

2.2. Supervision in public accounting .................................................................. 14

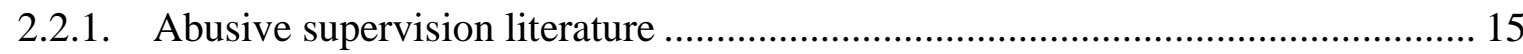

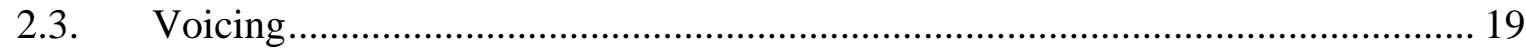

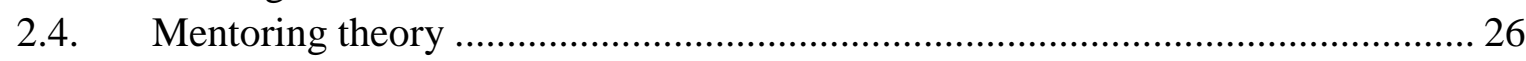

2.4.1. Mentoring research in an accounting context ................................................ 27

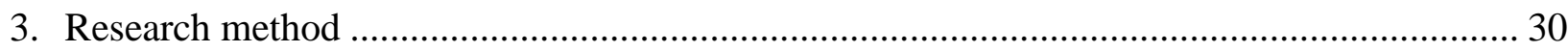

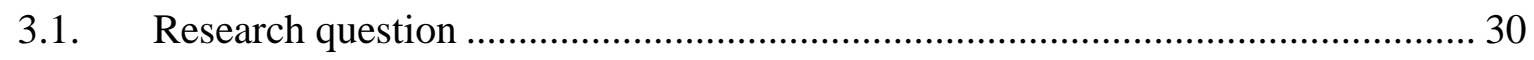

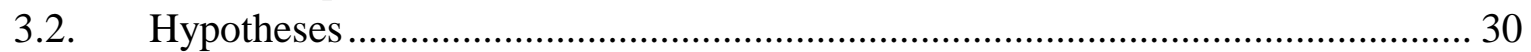

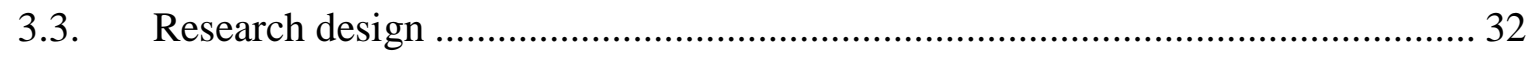

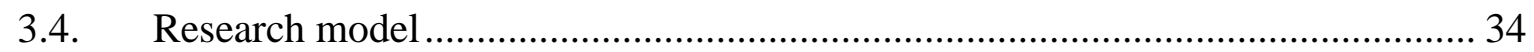

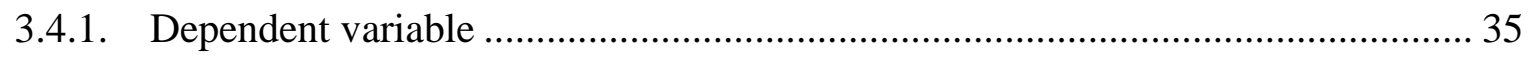

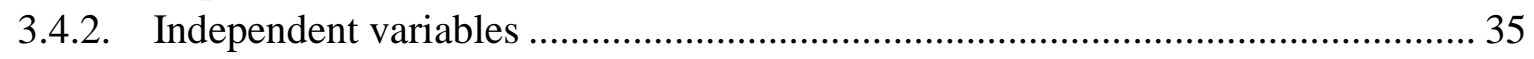

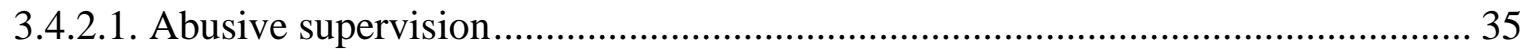

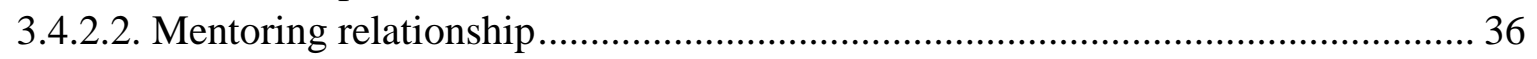

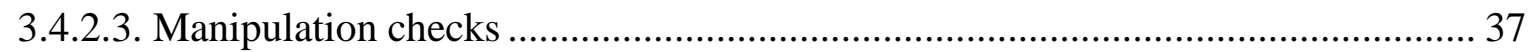

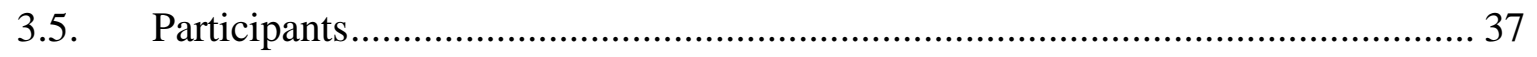

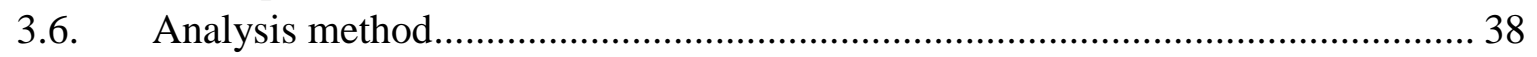

3.6.1. Conditioning variables .................................................................................. 39

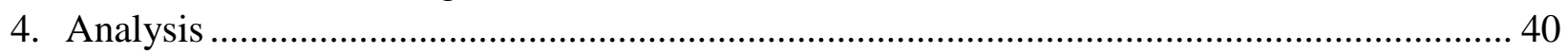

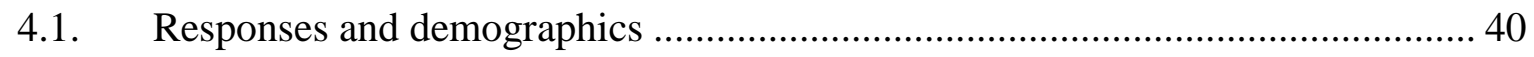

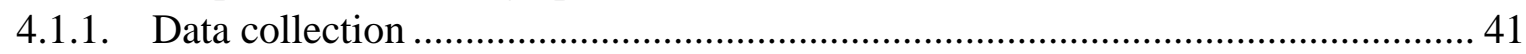

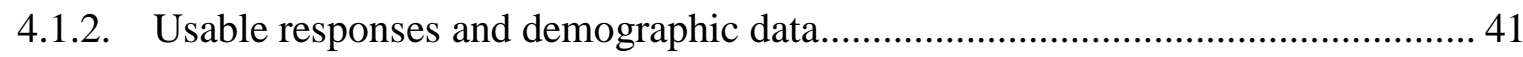

4.1.3. Demographic effects on variables.................................................................. 42

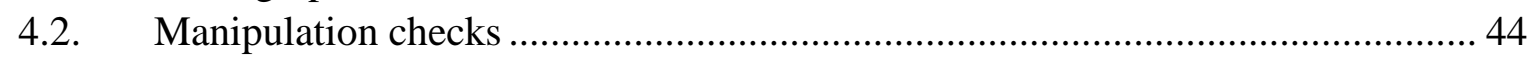

4.2.1. Abusive supervision manipulation check ............................................................ 44

4.2.2. Mentor relationship manipulation check ……….............................................. 45

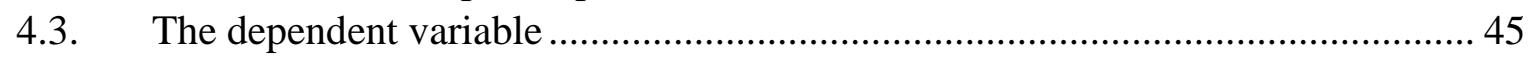

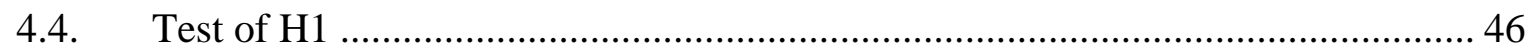

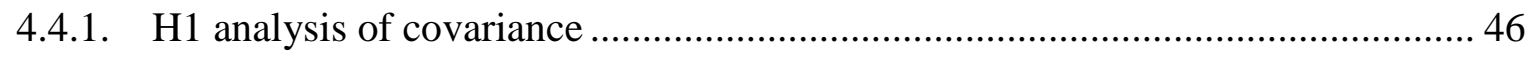

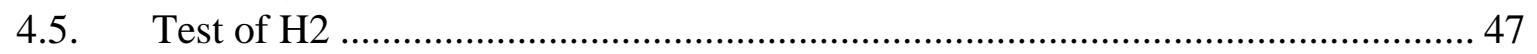

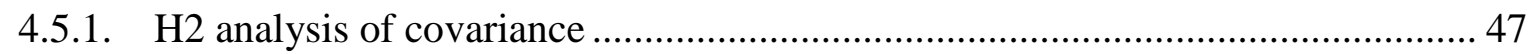

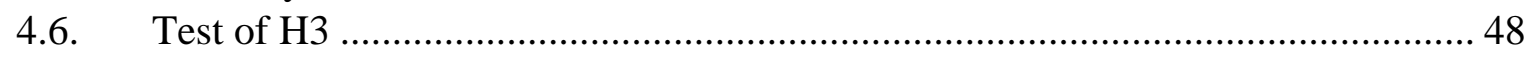

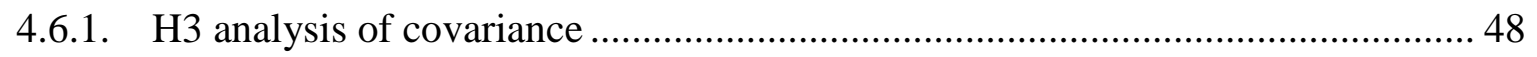




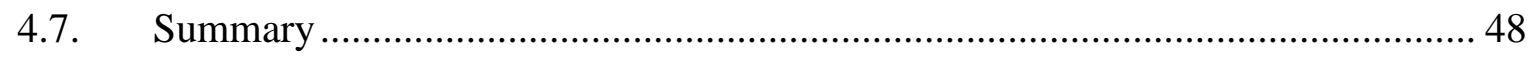

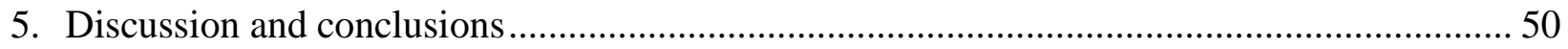

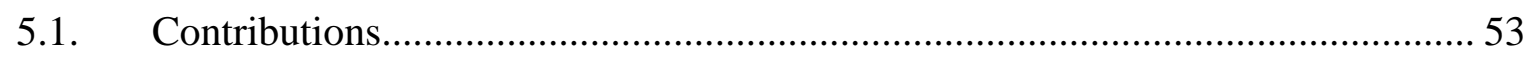

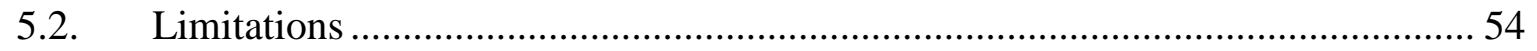

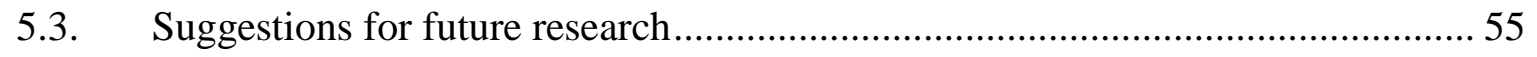

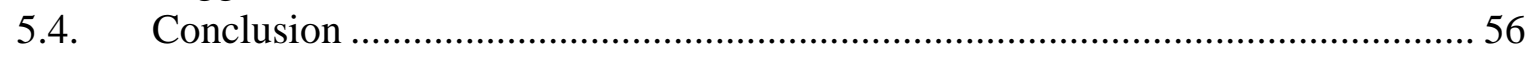

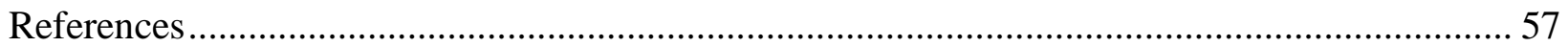

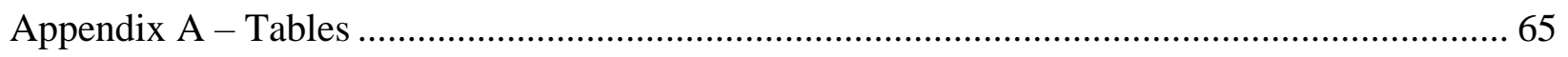

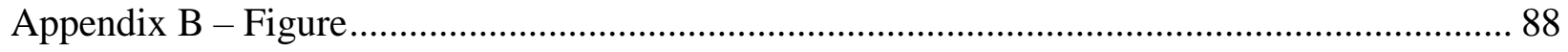

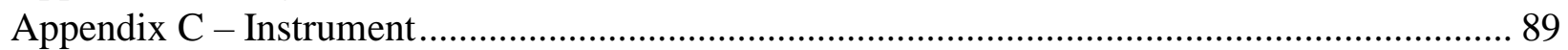




\section{AN INVESTIGATION OF FACTORS AFFECTING WILLINGNESS TO 'INTRODUCE THE ELEPHANT IN THE ROOM'}

\section{Introduction}

In front of over 400 faculty and students packed into McConomy Auditorium in August 2007, Dr. Pausch, a computer science professor at Carnegie Mellon University, introduced his elephant in the room - a terminal cancer diagnosis in the bloom of his career. Dr. Pausch succumbed to pancreatic cancer early the following year. When I applied to West Virginia University's Ph.D. in Business Administration program, I wrote a personal statement based largely on Dr. Pausch's last lecture "Really Achieving Your Childhood Dreams." My graduate education process has created an opportunity most Ph.D. candidates never experience. So, here is my elephant in the room: I lived my dissertation. All the major aspects discussed in the following sections derived from my personal experiences: (1) abusive supervision, (2) voicing, and (3) a mentor that revealed to me that I had choices. I begin with a preamble that encompasses my personal interest in this topic and use a narrative account from Mr. Robert Boisjoly's (1993) Accounting Horizons article to weave my ideas together.

\subsection{Preamble}

I am passionate about historical events. In 1996, when I was in third grade, my teacher gave the class a reading lesson that would capture my interests for years to come. The lesson was on the Space Shuttle Challenger ${ }^{1}$ (Challenger) and its ascent failure 73 seconds into takeoff of mission STS-51-L. I do not recall the specifics of the lesson, only my interest was so compelling that I continued to learn about Challenger at every opportunity. When my Mom

\footnotetext{
${ }^{1}$ The Space Shuttle Challenger was named after the HMS Challenger, a steam-assisted corvette of the British Royal Navy. The HMS Challenger was commissioned to embark on the first global marine research expedition from 1872-1876. It was aptly named the Challenger expedition.
} 
gauged my interest and suggested attending a weeklong space camp a couple of years afterward, I jumped at the opportunity.

At space camp we learned about many of the technical (for fifth graders) aspects of space travel, including the topic of launch failures. We watched the video of the Challenger explosion and analyzed the communications that occurred prior to the tragedy. The weeklong camp culminated in the Friday mission simulation. Our group of seven was asked to select a Space Shuttle Mission Patch from a previous mission. My choice was easy; I honored the tenth mission for Challenger, STS-51-L.

So, that morning we donned our space gear (smocks with our selected patches glued on the sides) and crawled into our cabin (a three-room tent). We all also had our own roles. After our ascent, Houston asked a group member to "stir the oxygen tanks" and "switch the carbon dioxide tanks." During that process, a glitch occurred. The replacement $\mathrm{CO}_{2}$ tank was damaged during takeoff. A teammate quickly identified and removed the tank (remarkably similar to a 2liter Pepsi bottle) replacing it with the reserve tank. ${ }^{2}$ After returning to Earth, in our debriefing with Houston, we learned that he saved the day simply by following policies and procedures and maintaining the quality control standards in the cabin. Maintaining quality control standards brought me back to why the Challenger explosion was ever allowed to happen. One of our team members was able to prevent a disaster, at only 11 years old, because he observed quality control practices and acted accordingly.

Seventeen years later, my interest piqued again when I was shown an article in Accounting Horizons (Boisjoly, 1993) about the importance of personal integrity and accountability that was authored by one of the Challenger engineers. It was a perspective on the

\footnotetext{
${ }^{2}$ Prior to the launch, we were told there is a glitch on every mission. This "glitch" happened to be nearly identical to the process astronaut Jack Swigert was going through prior to the Apollo 13 explosion (NASA, 2001).
} 
Challenger launch that I had not yet heard. Ultimately, Boisjoly (1993) untangled and weaved together different interests in my life that have led to this dissertation.

Robert M. Boisjoly ${ }^{3}$ was employed as an aerospace engineer for the $\mathrm{NASA}^{4}$ contractor Morton Thiokol, Inc. (MTI). ${ }^{5}$ Mr. Boisjoly’s specialty area was on Space Shuttle Booster Joints. ${ }^{6}$ These joints fit together with rubber seals that expand and contract to keep the fuel in the rocket. ${ }^{7}$ Prior to the launch of Challenger, Mr. Boisjoly discovered that cooler temperatures (less than 53 degrees Fahrenheit) caused the rubber seals to contract to the point where fuel could escape, which would likely cause an external explosion. Cool temperatures nearly caused a failure in the years leading up to mission STS-51-L. Six months prior to the Challenger launch, Mr. Boisjoly wrote a portentous memo warning of the catastrophic loss of life that could occur in a cool weather launch (Martin \& Yee, 2012). MTI and NASA were keenly aware of the risks that cool temperatures posed on a mission.

Prior to the launch of mission STS-51-L, Mr. Boisjoly and other engineers on his team at MTI discussed the issues regarding launching in cold weather. Unseasonably cold temperatures (below freezing) were predicted for Cape Canaveral, FL for the morning of the scheduled flight. The engineers had no trouble reaching the decision to not launch in the event of cold weather based on existing quality control criteria; they voiced loudly their concerns to MTI management

\footnotetext{
${ }^{3}$ Mr. Boisjoly was not a Professional Engineer (P.E.) at the time of the ascent failure. After the disaster, Mr. Boisjoly sensed his time at MTI was waning and he began the process to become a P.E. to provide for his family. ${ }^{4}$ The National Aeronautics and Space Administration (NASA) is an independent agency of the U.S. in charge of the civilian space program and aerospace research.

${ }^{5}$ Morton Thiokol, Inc. was founded in 1929 by two chemists who invented synthetic rubber. In 1945, the Company shifted to rocket propulsion technology. In 2007 it was acquired by ATK Launch Systems Group (ATK), a U.S. company.

${ }^{6}$ In layman's terms, when looking at a space shuttle prior to launch, there is a large orange tank and two white rockets on either side of the tank. Boisjoly was an expert in how the white rocket pieces fit together (Space Shuttle Booster Joints).

${ }^{7}$ A common inquiry is why the rocket was assembled in pieces and not one solid cylinder. The answer is that Morton Thiokol, Inc. was based in Utah and the launch site is in Florida. The most economical way to manufacture the rockets was in Utah. Then the pieces would be shipped by rail to the launch site and assembled.
} 
and NASA. Unfortunately, NASA did not share that view. The mission had been delayed six times in the days leading up to the eventual launch. Over the course of several hours, NASA pressured MTI executives to give the "go ahead" for launch. Mr. Boisjoly, in his Accounting Horizons article $(1993,63)$, described the internal pressure that was placed on his engineering team to alter their decision. In Mr. Boisjoly's view, this pressure was an unacceptable override of quality control standards that were in place to increase the probability of a safe launch. ${ }^{8} \mathrm{Mr}$. Boisjoly viewed the tactics used as abusive and violative of his personal integrity. After the ascent failure of Challenger that killed six astronauts and a school teacher from New Hampshire, Mr. Boisjoly voiced his concerns before the U.S. Congress in the formal investigations that ensued. Mr. Boisjoly eventually left MTI, never to work in the aerospace industry again. Mr. Boisjoly's personal experience added to my interest about the Challenger disaster: what went wrong, and why? The lessons of Challenger apply to accounting and business. Policies and procedures exist to provide checks and balances that assure objectives are achieved. To begin, I turn my focus to a brief discussion on the overarching aspects of this study.

\subsection{Overview}

The purpose of this study is to examine voicing and how it is influenced by abusive supervision and mentorship. In the preamble, Mr. Boisjoly described voicing in the face of abusive supervision. Mr. Boisjoly was the living embodiment of how ignoring the "elephant in the room" or violations of policies and procedures adversely affected the ability of NASA officials to uphold quality standards. By ignoring the "elephant in the room" addressed by Mr. Boisjoly, NASA officials caused the tragic deaths of the six-member Challenger crew and a school teacher, Christa McAuliffe.

\footnotetext{
${ }^{8}$ The technical details of the launch decision tree are noted in Boisjoly (1987).
} 
The profession of public accounting has continuously emphasized the importance of quality in the individual practitioner and in the firm's practice. In 1979, the American Institute of Certified Public Accountants (AICPA), through its Auditing Standards Board, released the first Statement on Quality Control Standards (SQCS). These standards provide a framework for quality at the CPA firm level. The quality of the entire accounting profession depends upon the collective performance of CPA firms, which is built upon the performance of the underlying individual accountants. If an accountant acts in an inappropriate way, then the corresponding CPA firm bears the effects. To the extent that such deeds are widespread, the whole profession is placed at risk. ${ }^{9}$ This domino effect potentially discredits the entire profession, leading to a crumbling of the underlying framework that built the profession. Quality control is vital for the profession that serves the public interest.

Supervision is an essential feature in accounting quality and was one of the original nine elements of SQCS No. 1 (AICPA, 1979, 3). Currently SQCS No. 8 (AICPA, 2012) identifies the importance of effective supervision, which is emphasized in three of the six essential elements: (1) engagement performance (\$10.35.b), (2) monitoring (\$10.60), and (3) human resources (§10.31). Supervision as a quality mechanism in the accounting literature is largely unaddressed. I focus on three key elements from SQCS No. 8 that provide a specific organizational context for my study. The first element, engagement performance, describes the supervisor's responsibilities in maintaining legal, regulatory, and ethical requirements. A second element, monitoring, addresses how a concern that is voiced should be dealt with internally by the firm. The human resources element requires establishing competency, capability, and ethics among the

\footnotetext{
${ }^{9}$ Largay (2002), then the editor of Accounting Horizons, a professor at Lehigh University, and an alumnus of Arthur Andersen, described Arthur Andersen's demise as a watershed event. He summarized the risk to the system that Arthur Andersen caused and offered suggestions to fix it.
} 
firm's personnel. SQCS No. 8 notes that competency, capability, and ethics can be achieved specifically through mentoring.

Voicing is an important factor used to maintain quality in the accounting profession, and yet it has received limited attention in the accounting literature. Nelson, Proell, and Randel (2016) presented voicing to the accounting literature. To date, research in accounting has been narrowly focused around whistleblowing, which is a legal concept that involves a report of a violation of a law or regulation to parties outside the entity (Moberly, 2006). An environment that encourages voicing within the organization is a way to maintain quality in the firm because potential violations of policies and procedures can be addressed by supervisors before they evolve into legal problems. While voicing can help firms maintain quality, other actions may suppress those intentions.

Abusive supervision exists in a variety of contexts and across organizations; the cost is an estimated \$23.8 billion annually in the U.S. (Tepper, Duffy, Henle, \& Lambert, 2006). Literature from management and psychology reveals high-pressure workplaces are at risk of becoming abusive workplace environments (Russell, Ferris, \& Sikora, 2016). The abusive supervision construct was originally developed in the management literature. Abusive supervision differs from other negative workplace behaviors (e.g., workplace bullying) because it is hierarchical in nature (Tepper, 2000). Abusive supervision research is based solely upon the subordinate's perceptions. Studies have suggested investigating abusive supervision in contexts beyond general business (Ashkanasy, Bennett, \& Martinko, 2016; Mackey, Frieder, Brees, \& Martinko, 2015; Russell et al., 2016). Examining abusive supervision in the accounting profession is a fruitful area for future exploration given the unique nature of public accounting and its role in protecting the public interest. By conducting an exploratory study in the 
professional accounting context, I inform the accounting, management, and psychology literatures.

Mentoring research dates to Kram's (1983) original work examining mentor/protégé pairs. Dirsmith, Covaleski, and Samuel (2015) described how mentors help protégés in public accounting to navigate firm politics. They chronicle how a mentor can help advance a protégé within the firm, making the protégé more visible to superiors. Dalton, Davis, and Viator (2015), found that having a mentor reduced the negative effects of unfavorable supervisory feedback in public accounting firms. Considering the extant research on abusive supervision, voicing, and mentoring, I arrived at the following research question: Does a mentoring relationship assist a protégé to voice in an adverse situation with an abusive supervisor?

To study the effect of abusive supervision and mentoring on voicing behavior, I developed three hypotheses. With literature from Tepper (2000) and Mackey et al. (2015), I predicted that an abusive supervisor would decrease a protégé's willingness to voice a violation of policies and procedures. A second hypothesis based on Kram (1983) and Dalton et al. (2015) predicted a mentoring relationship would increase voicing by a protégé when there is a violation of policies and procedures. A third hypothesis tested the interaction between abusive supervision and mentoring on voicing. To test my hypotheses, I developed a $2 \times 2$ quasi-experiment by manipulating both an abusive supervisor (high/low) and a mentor relationship (high/low). The dependent variable, voice, was a composite measure based on two responses measured on a seven-point scale. The four treatment conditions were randomized in a vignette that placed the participants in a firm where a colleague may have exposed client data. Participants consisted of a convenience sample of graduate and undergraduate students who proxied for professional 
accountants. Responses were captured through the online software Qualtrics ${ }^{\circledR}$ using both-in person and remote data collection.

In this study, I integrate three streams of literature in the organizational context of public accounting. The results of my study inform not only the accounting literature, but the management literature, psychology literature, and accounting professionals. The existence of high performance work systems, which exist in public accounting, are typically linked to positive workplace outcomes (Pichler, Livingston, Ruggs, \&Varma, 2016). However, those systems may create a risk for abusive supervision and should be investigated (Pichler et al., 2016, 244). Voicing allows for potential problems to be addressed to maintain quality not only for the individual accountant, but the CPA firm, and the profession as a whole. The positive effects of having a mentor have long been established (e.g., Allen, Eby, Poteet, Lentz, \& Lima, 2004; Dirsmith \& Coveleski, 1985, Kram, 1983). Therefore, it is expected that a mentoring relationship can reduce the negative effects of abusive supervision through voicing.

In Chapter 2, I present the necessary background information for the organizational context of my study using relevant policies and procedures from the AICPA. I also discuss three relevant literatures on supervision, voicing, and mentoring. In Chapter 3, I describe the development of the hypotheses, research model, quasi-experiment, participants, and variables. The analysis of each hypothesis is described in Chapter 4. Finally, in Chapter 5 I discuss the findings, limitations, and research conclusions. 


\section{Review of the Literature}

The purpose of this chapter is to provoke interest in my study by summarizing and synthesizing professional standards and relevant literatures. I begin by exploring the relevant policies and procedures from the AICPA that provide the organizational context for my study. I review and synthesize three individual streams of literature: (1) supervision, (2) voicing, and (3) mentoring. Throughout this chapter I rely on Mr. Boisjoly's narrative to weave my ideas together. These three streams then lead to my hypotheses (Chapter 3).

\subsection{Organizational context}

The accounting profession is dedicated to providing relevant and reliable financial information to the public. It is that unique function that aligns accounting more closely to professions such as medicine and engineering. For instance, medical professionals must protect, restore, and promote the good health of their patients in the interest of public health. Similarly, the engineering profession has a duty of trust, competence, safety, welfare, and quality assurance that serves the public's safety. All three of these professions issue licenses to individuals who demonstrate competency and the requisite knowledge. Medical doctors must pass the United States Medical Licensing Examination to become certified to practice medicine. Engineers must pass a rigorous exam and meet state requirements in order to become a

Professional Engineer (PE). An accountant must meet statutory requirements and pass a multipart examination to become a Certified Public Accountant (CPA).

A CPA in public practice works for a CPA firm, which is comprised of one or more CPAs depending on its size. Estimates place the total number of CPA firms in the U.S. around 85,000 (Accounting Today, 2016; Parker, 2012). CPA firms have some distinguishing facets that should be carefully considered when generalizing to other disciplines. CPA firms vary 
widely in size and scope, which can be broken down by size and professional service lines. The most recognizable CPA firms are the Big 4: (1) Deloitte, (2) EY, (3) KPMG, and (4) PwC. ${ }^{10}$ The Big 4 firms are the largest CPA firms in the U.S., have an international presence, and provide all of the basic services of a CPA firm: (1) accounting and bookkeeping services, (2) auditing and assurance services, (3) tax services, and (4) management consulting and risk advisory services. National or regional firms are smaller than the Big 4, but compete for the same business and provide the same basic services. These firms may also have an international presence. Finally, the smallest CPA firms are categorized as local firms. It is rare, but not unheard of, for a local firm to have an international presence. Typically, local firms consist of fewer than 25 professionals. Many local firms specialize in a particular service (e.g., tax services but not consulting services). Regardless of the size and services provided, CPA firms generally maintain a similar hierarchical personnel structure.

The organizational structure of a CPA firm consists of partners or shareholders at the ownership level. CPA firms can be organized as a sole proprietorship, general partnership, corporation, limited liability company, or limited liability partnership. The Big 4 firms and many other CPA firms operate as a limited liability partnership because of its advantageous liability protection: the individual partner is not liable for the acts of others not under the partner's control. Below the ownership level are managers, supervisors, seniors, and assistants, respectively. Regardless of the hierarchical level of the accountant within the CPA firm, they must be concerned with the quality of the service performed. The nature of a quality service is carried throughout other professional levels like engineering and medicine. To address CPA

\footnotetext{
${ }^{10}$ The Big 4 names listed refer to the brand and global organization of each firm.
} 
firm quality, the AICPA promulgated SQCS, now in its eighth iteration, discussed in the next section.

\subsubsection{Benchmarking CPA firm practice quality}

For CPA firms, quality control is executing at a high standard a firm's professional responsibilities to its clients and the public (external decision makers). Sustaining quality control begins with the organizational structure of the firm and flows down through the execution of its policies and procedures. To maintain the quality control of the firm, the AICPA, through its Auditing Standards Board, promulgated SQCS. The current version is SQCS No. 8 (AICPA, 2012, §10.17), which contains six elements that guide a CPA firm to establish effective policies and procedures: (1) leadership, (2) acceptance and continuation of client relationships and engagements, (3) ethical requirements, (4) engagement performance, (5) monitoring, and (6) human resources.

[insert Table 1 here]

Leadership responsibilities within a CPA firm refer specifically to the "tone at the top." Through SCQS No. 8 the AICPA requires that the leadership assume responsibility for the firm. Issues that arise regarding quality control are absolutely the responsibility of the leadership. Beyond leadership, the CPA firm must also evaluate client relationships.

The acceptance and continuance of client relationships and engagements must be addressed. For this, a CPA firm should establish policies and procedures that provide the firm with reasonable assurance of (1) its competence to perform the engagement, (2) its compliance with legal and ethical requirements, and (3) the client's integrity. This standard applies to both existing and new client engagements. 
Policies and procedures in the quality control structure should also extend to the relevant ethical requirements the CPA firm must bear. In particular, the CPA firm must provide reasonable assurance its personnel comply with relevant ethical standards. The AICPA's Code of Professional Conduct establishes the requisite ethical standards a CPA must follow (AICPA, 2016).

Beyond the ethical requirements, a CPA firm must also be concerned with how well it is performing during an engagement. The CPA firm must meet the firm, legal, and regulatory standards established. In particular, the CPA firm must address (1) the consistency of quality, (2) supervision responsibilities, and (3) review requirements. The review responsibilities require that suitable personnel conduct the services the CPA firm provides. Additional, if a situation being evaluated by the CPA firm is contentious, a consultation should take place. This meeting should render a proper and just verdict and be documented.

To monitor a CPA firm, the firm itself should provide reasonable assurance that its policies and procedures are (1) relevant, (2) adequate, and (3) operating effectively. The firm must focus on service quality as the ultimate goal. To that end, if any complaints or allegations are launched, the firm should provide clear channels of support for the voicer. Not only should clear channels exist, but appropriate actions should take place to address the voicer's concerns.

The human resources aspect refers to policies and procedures. Within this element, a CPA firm must provide reasonable assurance that its personnel meet competency, capability, and ethical requirements to perform the essential functions of a CPA firm's practice. An accountant placed into a role should be able to perform the duties assigned and develop the necessary competencies to advance to the next hierarchical level. 
CPA firms also must be enrolled in an AICPA practice-monitoring program in addition to adhering to the six elements prescribed by SQCS No. 8. A practice-monitoring program is referred to as peer review (currently required on a triennial basis), which is the evaluation of the firm's compliance with SQCS by a team of qualified peer reviewers (Reinstein \& Apostolou, 2015). The CPA review firm gauges whether or not the CPA firm under review has developed and implemented adequate policies and procedures. Consider the following: the quality of the entire accounting profession is built upon the collective CPA firms, which are supported by the underlying individual accountants. Therefore, if an individual accountant commits an act that is unbecoming to the profession, then the CPA firm associated with the CPA also bears a cost, and the profession itself suffers reputational effects. Thus, affirming that quality control measures are met through peer review is essential.

For my study, I isolate three aspects from SQCS No. 8 (AICPA, 2012): (1) engagement performance, (2) monitoring, and (3) human resources. Engagement performance describes the supervisor's responsibilities in maintaining legal, regulatory, and ethical requirements (AICPA, 2012 , §10.35). I refer to this aspect as supervision. Next, the monitoring function addresses how a concern that is voiced should be dealt with internally by the CPA firm (AICPA, 2012, §10.60). I refer to this aspect as voicing, consistent with Boisjoly (1993). Finally, human resources requires establishing competency, capability, and ethics among a firm's personnel (AICPA, $2012, \S 10.31)$. One way to achieve this outcomes is through mentoring, which has a rich presence in both the management and accounting literatures (AICPA, $2012 \S 10 . A 19)$. I refer to the human resources aspect as mentoring. 


\subsection{Supervision in public accounting}

To provide a framework for quality in the accounting profession, the AICPA released SQCS No. 8 in 2012. Supervision is an essential feature in accounting practice quality. I begin this section with a discussion about the requirement and expectation for supervision through three of the elements contained in SQCS No. 8. Additionally, I supplement the discussion of supervision with "tone at the top." After, I shift the discussion to abusive supervision, which is integrated with Mr. Boisjoly's experience. I then review and synthesize the relevant abusive supervision literature summarized in Table 2.

[insert Table 2 here]

Supervision was one of the original nine elements of SQCS No. 1 (AICPA, 1979, 3) and called for the establishment of policies and procedures, “...for the conduct and supervision of work at all organizational levels ... to provide the firm with reasonable assurance that the work performed meets the firm's standards of quality." In the most current iteration, SQCS No. 8 (AICPA, 2012) highlights the importance of effective, indeed quality, supervision, which is emphasized in three of the six essential elements: (1) relevant ethical requirements (\$10.21), (2) human resources (§10.31), and (3) engagement performance (§10.35.b).

A firm should provide reasonable assurance that its personnel abide by the ethical requirements. In human resources, sufficient levels of personnel must be maintained to perform engagements to meet professional standards, legal requirements, and regulatory requirements. Finally engagement performance must allow for policies and procedures that outline the supervisor's responsibilities during an engagement. 


\subsubsection{Abusive supervision literature}

Literature exists that reveals a sustained high performance workplace is at risk of fostering abusive supervisors. To illustrate how a high-performance workplace may evolve into an abusive situation, I refer to the Challenger ascent failure. After several delays to the launch of mission STS-51-L, the launch was again threatened due to unseasonably cold weather moving through south Florida. Even with the cold, the engineers at MTI were pressured by management to approve the launch. Overriding the engineers' decision resulted in the deaths of six astronauts and a teacher. After the ascent failure, Mr. Boisjoly was assigned to the "failure investigation team" (Boisjoly, 1993, 65). He chose to voice information (his truth), which was contrary to the views stated by a general manager of MTI during a public hearing. After, Mr. Boisjoly was removed from the failure investigation team, ostracized, and isolated within his own organization- simply for telling the truth.

Abusive supervision exists in a variety of contexts and across organizations with a significant negative financial impact. ${ }^{11}$ The construct was originally developed in the management literature (Tepper, 2000). Since that time, studies have attempted to distinguish abusive supervision from related constructs (e.g., petty tyranny, workplace bullying). Tepper $(2000,178)$ defined abusive supervision as "[s]ubordinates' perceptions of the extent to which their supervisors engage in the sustained display of hostile verbal and non-verbal behaviors, excluding physical contact." This construct suggests that the perceptions of the subordinate evolve through continued interactions with the supervisor (Chan \& McAllister, 2014; Klaussner, 2014). Manifestations of abusive supervision may include: (1) coercion, (2) inconsiderate actions, (3) loud and angry tantrums, (4) public criticism, and (5) rudeness. Research has

\footnotetext{
${ }^{11}$ Abusive supervision is a perception and may not constitute actual abuse. Likewise, a subordinate may perceive abusive supervision while the supervisor does not perceive actions to be abusive.
} 
considered abusive supervision in justice theory, which is used as the primary explanatory framework (Mackey et al., 2015). ${ }^{12,13}$ The perceptions of abusive supervision likely stem from a subordinate's inferences about fairness of supervisory justice (Klaussner, 2014). In sum, abusive supervision is based upon the supervised individual's perceptions, which may or may not be real. Namie and Namie (2000) estimate that between $10 \%$ and $16 \%$ of employees experience abusive supervision. Sheehan, McCarthy, Barker, and Henderson (2001) estimate the cost to the organization of abusive supervision (e.g., absenteeism, legal costs, organizational turnover, reduced productivity) is between $\$ 17,000$ and $\$ 24,000$ per serious incident. These estimates led Tepper et al. $(2006,119)$ to place the annual cost of abusive supervision in the U.S. at a conservative total of $\$ 23.8$ billion per year.

Tepper (2000), in the initial abusive supervision study, defined the construct and developed a 15-item measure of abusive supervision, which was adapted from other nonphysical abuse scales in different types of relationships (e.g., psychological abuse in dating relationships). The measure was validated with the use of MBA students (T1: $n=712,53.0 \%$ response rate and T2: $n=362 ; 50.8 \%$ response rate); a confirmatory factor analysis was conducted with working individuals recruited through random digit dialing over two periods. The results from Tepper's (2000) study revealed that abusive supervision led to several dysfunctional consequences: (1) higher turnover, (2) less favorable attitudes towards job, life, and organization, (3) greater work and family life conflict, and (4) intense psychological distress. When subordinates had less job mobility, the effects of abusive supervision were more pronounced for (1) job satisfaction, (2)

\footnotetext{
12 Justice theory is derived from fairness and equity theory (Adams, 1963; Folger \& Cropanzano, 2001), which has overlaps with social exchange theory (Blau, 1964; Cropanzano \& Mitchell, 2005).

13 Tepper (2000) developed the abusive supervision construct using Bies and Moag's (1986) interactional justice theory, which was developed anecdotally after Ph.D. students perceived unfair and varying treatment by faculty members.
} 
family-to-work conflict, (3) depression, and (4) emotional exhaustion. Subsequent studies found similar results (e.g., Breaux, Perrewé, Hall, Frink, \& Hochwarter, 2008; Burton \& Hoobler, 2011; Carlson, Ferguson, Perrewé, \& Whitten, 2011).

In a review of extant literature, Tepper (2007) examined and defined the eight different constructs used in nonphysical supervisory hostility: (1) abusive supervision, (2) generalized hierarchical abuse, (3) petty tyranny, (4) victimization, (5) workplace bullying, (6) supervisor aggression, (7) supervisor undermining, and (8) negative mentoring experiences. All of these constructs can encompass, or have the potential to encompass, a component of downward hostility (summarized in Table 3). Research also investigated the antecedents and outcomes of abusive supervision. Most studies examined outcome variables, some of which included work attitudes, psychological distress, work-family conflict, job satisfaction, deviance, emotional exhaustion, and problem-drinking. Finally, Tepper (2007) introduced a refined "emergent" model of abusive supervision complete with mediators, moderators, antecedents, and outcomes. Tepper's (2007) chief critique of ongoing abusive supervision research focused on the lack of theoretical application to the construct.

[insert Table 3 here]

Mawritz, Mayer, Hoobler, Wayne, and Marinova (2012) studied the progression of abusive supervision from executives to management to employees ( $n=383$ pairs, $75.2 \%$ response rate). They found abusive manager behavior is positively associated with abusive supervisor behavior, which is positively associated with work group interpersonal deviance (i.e., abusive behaviors directed at other organizational members). Additionally, the effects of abusive supervision are exacerbated in an environment that exhibits signs of a hostile work environment. 
In this context, a hostile work environment was defined as "consistent acrimonious, antagonistic, and suspicious feelings within the workgroup" (Mawritz et al., 2012, 327).

Martinko, Harvey, Brees, and Mackey (2013) reviewed the literature regarding abusive supervision in two time periods (2000-2007 and 2008-2012). In the first time period, the authors summarized research preceding Tepper's (2007) review, followed by the research from 20082012. Martinko et al. (2013) related the second wave of studies to Tepper's (2007) future research suggestions. The antecedents, outcomes, and moderators of abusive supervision are described along with a more comprehensive abusive supervision model in comparison to the Tepper (2007) model. The authors discussed five supervisor-level antecedents of abusive supervision: (1) stress, (2) conflict levels, (3) deep-level dissimilarity, (4) emotional intelligence, and (5) histories of family undermining (Martinko et al., 2013, p. S126). Four outcome variables include (1) aggression/deviance, (2) psychological distress, (3) family well-being, and (4) resistance. Four moderating variables include (1) physical exercise, (2) organizational-based self-efficacy, (3) performance evaluations, and (4) low-quality leader-member exchange relationships. The outcomes of abusive supervision described by Martinko et al. (2013) are presented in Table 3.

Mackey et al. (2016) conducted a meta-analysis $(k=140)$ to determine population estimates for abusive supervision and various demographic, antecedent, and outcome variables previously examined since the construction of Tepper's (2000) measure. Various adaptations of the instrument allows for the possibility of measurement artifacts (Humphrey, 2011). The results of Mackey et al.'s (2016) meta-analysis suggested that practitioners should be concerned about employees' perceptions of abusive supervision. The results pointed toward a wide range of employees who report perceptions of abusive supervision. Additional results indicated that 
perceptions of abusive supervision are negatively associated with perceptions of justice in the workplace. Finally, Mackey et al. (2016) showed an association of the perceptions of both abusive supervision and negative leadership (e.g., ethical leadership). A wide variety of organizational and personal outcomes (e.g., organizational citizenship behavior) are associated with the perceptions of abusive supervision. Mackey et al. (2016) recommend researchers applying justice theory in abusive supervision research recognize the central role that perceptions play in the abusive supervision construct. With the breadth of research on abusive supervision since Tepper's (2000) seminal study, Mackey et al. (2016) suggested future researchers test the boundaries of the effects of perceptions of abusive supervision. Recent legislative actions have been introduced to address abusive workplace behaviors (Mackey et al. 2016). ${ }^{14}$ A key aspect to this study is investigating how abusive supervision influences subordinates reactions when a discordant situation arises; notably whether the individual will voice to a more senior member of the firm.

\subsection{Voicing}

Voicing has a rich history in both the management and psychology literatures. Only recently has the topic of voicing been studied in accounting (Nelson et al., 2016). In this section, I begin by distinguishing between voicing and whistleblowing. I then illustrate the bright line distinction through Mr. Boisjoly's experience followed by a synthesis of the relevant literature from both management and accounting, which is summarized in Table 4.

\section{[insert Table 4 here]}

While all whistleblowing is voicing, all voicing is not whistleblowing. Consider the classic definition of whistleblowing from Near and Miceli (1985, 4):

\footnotetext{
${ }^{14}$ As of April 2017, 32 legislatures have introduced a healthy workplace bill (Healthy Workplace Bill, 2017).
} 
We, therefore, define whistle-blowing to be the disclosure by organization members (former or current) of illegal, immoral or illegitimate practices under the control of their employers, to persons or organizations that may be able to effect action.

Now examine the definition of voicing (Bashshur \& Oc, 2015, 1531):

...we define voice as the discretionary or formal expression of ideas, opinions, suggestions, or alternative approaches directed to a specific target inside or outside of the organization with the intent to change an objectionable state of affairs and to improve the current functioning of the organization, group, or individual.

Also consider the definition recently used in an accounting study by Nelson et al. $(2016,1784)$, which is from Burris, Detert, and Chiaburu (2008, 22):

Voice is defined as the verbal communication of problems or ideas intended to stimulate organizational improvement to superiors with the perceived power to take action.

A strict interpretation of whistleblowing fails to account for the disclosing of a policy and procedure violation. A violation of policies and procedures is not necessarily (1) illegal, (2) immoral, or (3) illegitimate. However, an employee may perceive that type of violation as something worth reporting upward in the firm's hierarchy. From a manager's perspective, it may be a perfectly permissible exception. However, too many management exceptions create a slippery slope to (1) illegal, (2) immoral, or (3) illegitimate behavior. Regardless of whether or not the behavior meets these thresholds, disclosing, for instance, a policy or procedure violation is voicing (i.e., not whistleblowing). However, from a strict standpoint, the case may require an ethical judgment. ${ }^{15}$

\footnotetext{
${ }^{15}$ Derived from Rest's (1986) model on the ethical reasoning process, an ethical action is the follow through of an intent to act that was caused by an ethical evaluation after an ethical dilemma was recognized. My research is not concerned with judging the complexity of ethical issues associated with voicing a concern, although those are certainly important. Rather, I focus on the practical application of voicing a concern to a perceived violation of policies and procedures.
} 
In the case of Mr. Boisjoly, the engineers on the launch team concluded the proposed launch date would pose too great a risk because of the cold forecasted temperatures. Mr. Boisjoly and a fellow engineer pressed hard to delay the launch at STS-51-L. The decision to launch Challenger on January 28, 1986 occurred after NASA and managers at MTI overrode the engineers. While Mr. Boisjoly voiced his concern to management, the behavior of management was not (1) illegal, (2) immoral, or (3) illegitimate, and no criminal charges ever arose from the decision to launch Challenger. However, after the disaster, Mr. Boisjoly was publicly referred to as a whistleblower and blacklisted from his profession simply for following procedure and expressing his professional assessment to management. Mr. Boisjoly made the decision to voice his concerns to address the critical errors and the override of policies and procedures led to the decision to launch Challenger.

The fundamental issue with voicing a concern that leads to marginalization is that, primitively, there is a greater risk of death (Joubert, 2006; Power \& Compion, 2009). In the academic literature, this concept is known as "retaliation risk" or "...undesirable action taken against a whistleblower ${ }^{16}$ —in direct response to the whistleblowing — who reported wrongdoing internally or externally, outside of the organization" (Rehg, Miceli, Near, \& Van Scotter, 2008, 222). Previous studies explored the mechanisms to arrive at an ethical judgment (e.g., Rest, 1986; Mintz, 2016), and examined the reporting channels (e.g., other superiors, hotlines, external enforcement agents, and audit committees) available to those who elected to voice a concern (Kaplan, Pope, \& Samuels, 2010). Legal definitions of whistleblowing refer to a formal external reporting function in which the information is disclosed to someone outside of the organization (Moberly, 2006). However, these definitions are beyond the scope of voicing a concern of a

\footnotetext{
${ }^{16}$ All whistleblowing is voicing, but not all voicing is whistleblowing.
} 
violation of policies and procedures within the organization and in the bounds of positional authority.

Mr. Boisjoly, in his 1993 Accounting Horizons article, described the three options available to an individual who has observed or perceived a violation of policies and procedures: (1) exit, (2) voice, or (3) remain loyal [to the firm] ${ }^{17}$ Exiting is the choice made to extract oneself from an ethical confrontation by leaving the company or transferring to another department within the same company to avoid having to make a proper ethical decision (Boisjoly, 1993, 59). Voice is the option chosen by those who are willing to stand up for ethical principles in the belief that change will result (Boisjoly, 1993, 59). Remaining loyal is serving self-interests of career and organization with minimal objective reasoning of the consequences to others or the company (Boisjoly, 1993, 59). In the preface to Mr. Boisjoly's article, managing editor Jerry Arnold (1993) ${ }^{18}$ described why an engineer's story belongs in Accounting Horizons, and as difficult as it may be, voicing a violation is the only accepTable answer. ${ }^{19}$

Mesmer-Magnus and Viswesvaran (2005) (MM\&V) also outlined the three options Mr. Boisjoly presented as the only options present when facing an unsatisfactory situation. In their study, MM\&V conducted a meta-analysis $(k=26)$ of the whistleblowing literature. ${ }^{20} \mathrm{MM} \& \mathrm{~V}$ presented an analysis of the correlates and characteristics of both whistleblowing and retaliation. They also distinguished between intent and actual whistleblowing. To that time, there were only two studies that examined actual whistleblowing, which did not correlate strongly with intent [to

\footnotetext{
${ }^{17}$ Mr. Boisjoly bases his options on Hirschman's (1970) book Exit, Voice \& Loyalty: Responses to Decline in Firms, Organizations, and States.

${ }^{18}$ Jerry Arnold, Ph.D. is professor emeritus at the University of Southern California; he was the managing editor of Accounting Horizons from 1992-1994.

${ }^{19}$ Neither Boisjoly (1993) nor Arnold (1993) make reference to whistleblowing. I agree with this choice because whistleblowing was originally developed as a legal term (Nader, Petkas, \& Blackwell, 1972) before evolving to its present-day broad use.

${ }^{20}$ Relevant accounting research was excluded from the study, without explanation.
} 
blow the whistle]. However, MM\&V described the difficulties in conducting research with actual whistleblowers, which include (1) self-reporting, (2) access to longitudinal data, and (3) hindsight bias (Mesmer-Magnus \& Viswesvaran, 2005, 292). The authors concluded that there was currently not enough data to show a meaningful correlation between intent and actual whistleblowing, validating continued research on the subject. From the retaliation perspective, $\mathrm{MM} \& \mathrm{~V}$ showed that perceived supervisor support is negatively correlated with retaliation, which is the strongest finding in the retaliation portion of the meta-analysis. This finding highlighted the negative consequences a subordinate may face from an abusive supervisor to a voicing decision.

Since the MM\&V meta-analysis, several studies have made contributions to the literature in general and from an accounting perspective. Rehg et al. (2008) surveyed 3,288 Air Force employees, 1,224 of whom perceived wrongdoing. Among those who witnessed wrongdoing, women reported a higher perception of retaliation. Additionally, (1) lack of support from others and (2) low power were related to retaliation perception.

Kaplan et al. (2010) examined the extent to which an unsuccessful social confrontation with a supervisor influences a subordinate's reporting intentions to a supervisor's supervisor and an internal auditor. The authors employed a $2 \times 2$ between subjects design (fraud $\times$ social confrontation); misappropriation of assets/financial statement fraud $\times$ meeting (or not) with the transgressor. Participants were MBA students $(n=77)$. The findings suggested that subordinates who experienced unsuccessful social confrontation with a supervisor were more likely to seek out the supervisor's supervisor rather than an internal auditor. The authors suspected this decision was related to the relative power of the recipient of the report (Kaplan et al., 2010, 63). 
Seifert, Sweeney, Joireman, and Thornton (2010) examined whether whistleblowing increased when organizational whistleblowing procedures, outcomes, and related exchanges with superiors were perceived as fair. The authors used a $2 \times 2 \times 2$ factorial between-subjects design (procedures $\times$ interactions with management $\times$ outcomes) with internal and managerial accountants $(n=447)$. The findings indicated that whistleblowing policies and mechanisms incorporating higher levels of procedural, distributive, and interactional justice were perceived to increase the likelihood that an accountant would internally report a financial statement fraud.

Reporting intentions within accounting firms was more recently studied by Taylor and Curtis (2013). The authors examined third year audit seniors' likelihood of whistleblowing in a $2 \times 2$ experiment (organizational response $\times$ power distance). They found the likelihood of voicing was greater if the wrongdoer was a peer than if a superior. Additionally, a prior positive organizational response positively affected subsequent voicing likelihood.

Gao, Greenberg, and Wong-On-Wing (2015) examined whistleblowing intentions from the perspective of lower-level employees and reporting channels ( $n=273)$. In a $2 \times 2 \times 2 \times 2$ fully crossed experimental design (reporting channel $\times$ bystander $\times$ power status $\times$ case), the authors found that external reporting channels increased the intentions to whistleblow. This finding was in contrast to Kaplan, Pany, Samuels, and Zhang's (2009) study. Kaplan's (2015) commentary called for additional research evaluating the dynamics of multiple employees observing or becoming aware of wrongdoing, and their subsequent reporting intentions.

Nelson et al. (2016) examined willingness to voice in an auditing setting using a sample of auditors from two large firms. They conducted five experiments varying within and betweensubject designs to explore how a team oriented leader affects an auditor's willingness to speak up. Willingness to voice was higher when the leader was team-oriented and when the issues 
were aligned with the leader's concerns. The fear of consequences to voicing did not affect participants' willingness to do so.

As stated previously, Mr. Boisjoly (1993) classified the options a potential voicer must choose from as (1) exit, (2) voice, or (3) remain loyal [to the firm]. He viewed these as the only three reasonable options available. ${ }^{21}$ For purposes of my study, voicing refers to reporting a perceived violation of quality control policies and procedures to those in a position to effect change. Other studies examining retaliation often explored how the employee may "get even" for some perceived injustice (Siegel Christian, Christian, Garza, \& Ellis, 2012; Martinko et al., 2013). These examinations only partially examined the way a firm may influence the voice of a subordinate. In Mr. Boisjoly's case, he was the sacrificial lamb to sustain a viable firm (MTI). Unfortunately, he lost his career as an engineer, relegated to consulting for the remainder of his life and sharing his painful remembrances. ${ }^{22,23,24}$

I distinguish between whistleblowing and voicing. A violation does not need to be a violation of laws or statues that would constitute whistleblowing. As in Mr. Boisjoly's experience, the violation was management's override of the "MTI Assessment of Temperature Concern on SRM-25 Launch" (Arnold, 1993). To achieve that distinction, I began with a discussion of whistleblowing and voicing to clarify differences between the two separate

\footnotetext{
${ }^{21}$ Voicing is a more refined definition of speaking up than whistleblowing, which is a term that refers to the legal aspects of choosing to report a situation that violates a law.

${ }^{22}$ Mr. Robert Boisjoly died at age 73 from cancer of the colon, kidneys, and liver. Prior to his passing, Boisjoly was awarded the Prize for Scientific Freedom and Responsibility by the American Association for the Advancement of Science. He became outspoken on corporate governance topics and presented corporate ethics topics to more than 300 universities and civic groups (Martin \& Yee, 2012).

${ }^{23}$ An investigation by the Rogers Commission resulted in nine recommendations for improving the safety of the shuttle program. MTI ceded a \$10 million incentive fee without accepting liability for the accident (Jensen, 1996, 355).

${ }^{24}$ Post Hoc Ergo Propter Hoc - "After this therefore because of this," is a logical fallacy. It means, "one thing follows the other therefore it was caused by the other. But it's not always true. In fact it's hardly ever true." The thought of top-down ethics may not go far enough. While COSO speaks to corporate culture being top down, there may be a need for a "tone" at the middle, the side, or even the bottom.
} 
constructs. I summarize voicing (1) from Mr. Boisjoly's perspective and (2) the relevant literature. Finally, I conclud with the importance of voicing and how it applies in an accounting context.

\subsection{Mentoring theory}

Mentoring has a rich history in the accounting, management, and psychology literatures. I begin with a broad discussion on the topic before honing in on mentoring in an accounting context. Continuing with the theme, I conclude with Mr. Boisjoly's (1993) suggestions from his Accounting Horizons article. Table 5 summarizes the relevant mentoring literature.

[insert Table 5 here]

Contemporary mentoring research began with the pioneering work of $\operatorname{Kram}(1983,1988)$. However, the word "mentor" itself is rooted in Greek mythology. ${ }^{25}$ Kram (1983) developed a conceptual model of mentoring in a corporate setting based on the behavior and perceptions of 18 mentor-protégé pairs. She described how a mentor can buffer the negative effects that may be felt by the protégé in an adverse situation (Kram, 1988, 27). A mentoring relationship may be initiated formally or informally, but the mutually reciprocal nature of mentoring (i.e., both the mentor and protégé derive benefits) suggests that the relationship ensues because both the mentor and the protégé perceive the benefits to outweigh the costs and, therefore, willingly participate (Allen, 2007; Dougherty, Turban, \& Haggard, 2010; Harvey, McIntyre, Heames, \& Moeller, 2009; Kaplan, Keinath, \& Walo, 2001; Kram, 1988; Olian, Carroll, \& Giannantonio, 1993). ${ }^{26}$ A formal mentoring relationship is either (1) where the mentor and protégé are assigned

\footnotetext{
${ }^{25}$ Mentor was a long-time friend of Odysseus. When Odysseus left for the Trojan War, Athena disguises herself as Mentor in charge of his son's well-being. As Mentor, she offered encouragement to Telemachus, Odysseus' son. Thus the term "mentor" has evolved to refer to a role model who offers guiding wisdom and commitment to the development of the protégé's career.

${ }^{26}$ The mentor/protégé relationship has costs. Those costs may be higher when the mentoring relationship is mismatched. Costs include distractions from professional responsibilities, inconsistent guidance across mentors, poor advice, and interpersonal disagreements (Kram, 1988, 159-167).
} 
by the firm to one another or (2) where the mentor is the protégé's supervisor in the firm's hierarchy.

A successful mentor-protégé relationship values not only the mentor and protégé, but the organization as well (Allen \& Eby, 2010; Ragins \& Kram, 2007). In a metaanalysis on the outcomes of mentoring, Allen et al. (2004) found that the mentor-protégé relationship improves career satisfaction, effectiveness, and job advancement opportunities for the protégés. Mutually beneficial, the mentors gain satisfaction from a protégé's progress, and often find that their own career path is bolstered by participating in the protégé's success. Dirsmith et al. $(2015,178)$ described how a successful protégé bolsters the career of the mentor. The organization also benefits from the mentor/protégé relationship as contemplated by SQCS No. 8 (AICPA, 2012). A positive mentor/protégé relationship exhibits (1) decreased turnover, (2) enhanced job performance (Ragins \& Kram, 2007), and (3) increased firm loyalty (Hall \& Smith, 2009), which benefit the firm.

\subsubsection{Mentoring research in an accounting context}

Mentoring research suggests that to best understand mentoring relationships they should be studied in specific organizational contexts under differing conditions (e.g., Allen, Poteet, \& Burroughs, 1997; Kram, 1988; Kram \& Ragins, 2007). ${ }^{27}$ Barker, Monks, and Buckley (1999), studied chartered accountants from two Big 5 accounting firms in Ireland ( $n=287 ; 51 \%$ response rate) and found the protégé's perceived informal mentoring to be well-established and important to the career progress of public accountants. The career development aspect was found to be the strongest aspect of the mentoring relationship. Kaplan et al. (2001) conducted a survey of

\footnotetext{
${ }^{27}$ Viator and Pasewark $(2005,373)$ describe the two ways in which a public accounting firm context differs a typical business: (1) accounting firms are generally organized into service area with specialized training for professionals in those areas (e.g., auditing, tax, consulting services), and (2) public accountants typically gain expertise in a specific industry to achieve a comparative advantage in the marketplace and better serve their clients.
} 
auditor protégés ( $n=242 ; 12 \%$ response rate) and found that, in general, protégés perceived barriers to the mentor/protégé relationship to be low; obstructions to the relationship included firm size, gender, perceived willingness of the mentor, and access to a mentor. ${ }^{28}$ Viator (1999) studied CPAs in large accounting firms ( $n=723,24.2 \%$ response rate), and found that when neither the mentor nor protégé had input of determining the relationship pairing, satisfaction for the protégé was lower. Thus informal mentoring relationships were perceived as more beneficial to both the individual and the firm.

Herbohn (2004) studied mentoring among Australian accountants $(n=161 ; 40 \%$ response rate) and found (1) greater perceived barriers to the mentor/protégé relationship for local firm accountants, and (2) protégés receiving higher levels of support had lower organizational turnover intentions. Siegel, Reinstein, and Miller (2001) surveyed audit professionals ( $n=118$; $59 \%$ response rate) in public accounting firms and concluded that perceptions of fairness within the firm increased when respondents had a mentor. Finally, Dalton et al. (2015) surveyed public accountants $(n=421 ; 65.6 \%$ at the senior level) and found that the presence of an informal mentor ${ }^{29}$ tempers the negative impact of unfavorable supervisory feedback environments (i.e., an abusive supervisor).

Mr. Boisjoly (1993) offered advice to accountants in their professional work. One of the key principles Mr. Boisjoly argued for was a "top/down support and information flow." He also argued for firms to employ an ombudsman for instances in which typical reporting channels are ineffective. My interpretation of Mr. Boisjoly's argument is that a mentor may help support the voicing efforts of a protégé. In their commentary on qualitative research methods in accounting,

\footnotetext{
${ }^{28}$ The findings specifically are that local firm auditors perceived more barriers than large firm auditors, and women perceived fewer barriers than men.

${ }^{29} \mathrm{An}$ informal mentor is one outside of the supervisor-subordinate relationship.
} 
Dirsmith et al. (2015) described how mentors assists protégés in public accounting navigate firm politics. They discussed how a mentor helps advance a protégé within the firm, making him/her more visible to superiors responsible for promotion. Additionally, a mentor becomes someone who can "go to bat" for the protégé. When considered with the findings of Dalton et al. (2015), an interesting intersection can be explored. I extend mentoring theory within the accounting context by considering how CPA firm quality is improved by the presence of a mentoring relationship in an adverse situation. This extension is important because the accounting profession emphasizes quality within the firm as including mentoring (e.g., AICPA, 2012). The rich body of literature from across disciplines that supports mentoring in professional settings creates a framework that I use to investigate how mentoring affects voicing in an accounting specific context. 


\section{Research method}

In this chapter I first present the research question followed by three hypotheses. Next, I discuss the research design and research participants. I present my variable definitions and manipulation checks and my analysis method, including the research model and planned statistical tests. ${ }^{30}$

\subsection{Research question}

The purpose of this study is two-fold. First, I examine how a professional's decision to voice is affected by the perception of having an abusive supervisor. Second, I examine how a professional's decision to voice is affected by the presence of a mentoring relationship. Combined, I offer the following research question:

$\boldsymbol{R Q}$ : Does a mentoring relationship assist a protégé to voice in an adverse situation with an abusive supervisor?

\subsection{Hypotheses}

Abusive supervision was developed in the management literature as hierarchical workplace bullying. That is, the supervisor is perceived by the subordinate to be abusive by virtue of a sustained display of verbal and non-verbal behaviors (Tepper, 2000). Abusive supervision does not include physical contact. Mackey et al. (2016) suggest future research on abusive supervision should consider different contexts where the phenomenon occurs. In the accounting literature, Kaplan et al. (2010) examined subordinates' reactions to an unfavorable confrontation, but this falls short of being considered abusive supervision. Dalton et al. (2015) encourage research about abusive supervision specifically within an accounting context. Thus,

\footnotetext{
${ }^{30}$ The study reported in this dissertation received prior approval from West Virginia University's Institutional Review Board (Protocol \#1701406867).
} 
an accounting context is an appropriate one for an exploration of the abusive supervision construct.

Following proper policies and procedures is an effective way to maintain firm quality. The AICPA's Code of Professional Conduct describes the Principles and Rules all AICPA members must abide by to meet the minimum standards of the profession. Additionally, Statement on Quality Control Standards (SQCS) No. 8 (AICPA, 2012) contains three elements directly affecting supervision in accounting, (1) relevant ethical requirements, (2) human resources and (3) engagement performance. The elements layout the necessary requirements for policies and procedures to achieve adequate supervision in public accounting.

If an infraction violating policies and procedures is perceived, voicing the possibility is a way of maintaining quality in any firm. Prior research has shown that organizational commitment is lower for those who perceive abusive supervision (Mackey et al., 2016). Meanwhile, when organizational commitment is low, intent to whistleblow also is lower (Mesmer-Magnus \& Viswesvaran, 2005). Nelson et al. (2016) introduce voicing in the accounting literature as a way to stimulate organizational improvement. By focusing on voicing (instead of whistleblowing) I can hone in on violations of policies and procedures that may not yet be illegitimate, illegal, or immoral. This distinction allows for voicing to detect and correct a perceived violation before it results in illegal, immoral, or illegitimate activity. My research in the professional context is exploratory; findings in the management literature may not be generalizable to an accounting setting (Liang, Farh, \& Farh, 2012; Nelson et al., 2016). However, research has shown that professional settings can proxy for accounting settings (Kaplan et al. 2010). I propose the following hypothesis:

H1: Abusive supervision decreases the likelihood a protégé will voice a violation of firm policies and procedures. 
Mentoring has been the focus of both practitioners and academicians. Mentors and protégés both can benefit from the pairing from career and psychosocial functions. Informal mentors who are external to the supervisor-subordinate relationship can provide greater benefits to both the mentor and protégé. In the psychology literature, Allen et al. (2004) find that having a mentor is associated with greater career outcomes. Higher affective commitment is positively associated a protégé being mentored (Payne \& Huffman, 2005). SQCS No. 8 (AICPA, 2012) includes mentoring as a key feature to maintain the quality of the firm. In an initial study of mentoring pairs in accounting, Dirsmith and Covaleski (1985) discuss how non-formal communications influence a firm's control systems. With that, I offer my second hypothesis:

H2: The existence of a mentoring relationship increases the likelihood a protégé will voice a violation of firm policies and procedures.

Dalton et al. (2015) found that mentors reduce the negative effects of unfavorable supervisory feedback. Additionally, Dalton et al. (2015) call for future research to examine the buffering effects of negative workplace outcomes including abusive supervision. Therefore, I combine my first two hypotheses to create a third, the moderating effect of a mentoring relationship in the presence of perceived abusive supervision:

H3: The association between voicing and abusive supervision is moderated by the presence of a mentoring relationship, such that the presence of a mentoring relationship increases the likelihood of voicing a violation of firm policies and procedures.

[insert Table 6 here]

\subsection{Research design}

This study is an initial examination of abusive supervision, voicing, and mentoring in a professional context. Prior research investigating mentors and abusive supervision in accounting used survey based approaches (e.g., Dalton et al., 2015). To capture the specific constructs and 
their causal inferences, I isolate abusive supervision, voicing, and mentoring using an experimental methodology, which is appropriate to maintain internal validity regarding the assertions about the dependent and independent variables (Pedhauzer \& Schmelkin, 1991).

For this study, a vignette was developed where there is an abusive supervisor and a mentoring relationship. A survey was given to a class of 20 graduate-level accounting students with previous internship experience to help establish external validity. Of the 17 students who completed the survey, 11 had a past mentor and internship experience in an accounting setting. The students provided information regarding past voicing instances and mentoring experiences. The students responded to an open-ended prompt asking what a mentor was to them. The answers indicated their perception of a mentor was someone who offers guidance and assistance during difficult situations. The words "guidance," "assist," and "answers concerns" were used by 14 students. I also relied on past studies that employed an experimental methodology in the abusive supervision and mentoring literatures. Olian, Carrol, Giannantonio, and Feren (1988) manipulated the mentor's interpersonal competence in their vignette. I used the description of their experimental materials as a basis along with the material gathered from the graduate-level accounting students for the mentor manipulation. Burton and Hoobler (2006) manipulated abusive supervision in their vignette. Their experimental materials included an abusive supervisor in a low-level workplace setting. For this quasi-experiment, I adapted the setting to a professional entry-level position.

The abusive supervisor and mentoring relationship each had two conditions (high and low) resulting in a $2 \times 2$ fully crossed between-subjects design. The survey was administered online and in the classroom to graduate and undergraduate students (described in section 3.5) who were randomly assigned to one of the four possible conditions (refer to Table 7 and 
Appendix C). However, the possibility of confounding variables exists because the surveysetting lacks strict control. The possibility of confounding variables excludes the ability to make causal arguments. Thus, I refer to this study as a quasi-experiment. ${ }^{31}$

[insert Table 7 here]

My study is an initial examination of perceptions of abusive supervision in a professional context. Most prior research in abusive supervision and mentoring is survey-based (e.g., Dalton et al., 2016; Taylor \& Curtis, 2016; Viator, 1999). Survey-based approaches suffer from a lack of manipulated variables in a controlled setting, which makes causal attribution unattainable (Bloomfield et al., 2016, 378). This quasi-experimental approach is appropriate given the exploratory nature of the research and is commonly employed in the social sciences. ${ }^{32}$ Having participants assess the likelihood of voicing individually, rather than collectively, allows the focus to be on the individual participant's perceptions of abusive supervision. Likewise, this context allows for the individual to interpret the effect that a mentoring relationship would have on the likelihood of voicing.

\subsection{Research model}

The research model is described above and pictured in Figure 1. It included one dependent variable. Two independent variables and three conditioning variables are included. All three types of variables are discussed in the subsequent sections.

[insert Figure 1 here]

\footnotetext{
${ }^{31}$ More specifically, Aguinis and Bradley (2014) describe this type of methodology as an experimental vignette methodology that is used to balance internal and external validity. However, the conclusions may be ambiguous regarding causal relationships (Aguinis \& Bradley, 2014, 351).

32 Allen, Eby, O’Brien, and Lentz $(2008,348)$ reviewed 201 mentoring papers, which included 178 empirical articles. Only 5.1\% used an experimental approach, which led Allen et al. (2008) to encourage additional research using an experimental methodology. Scandura and Pelligrini $(2010,84)$ comment that "experimental laboratory research involving both random assignment and high experimental control could contribute greatly to our understanding of mentoring."
} 


\subsubsection{Dependent variable}

The dependent variable is voicing. There are typically two feasible options available to researchers to assess voicing: (1) a survey-based approach asking participants about past experiences in voicing, or (2) a quasi-experimental approach asking participants about their willingness to voice. After reading the vignette, the participants respond to two randomized statements to operationalize the voicing construct: (1) "You are willing to speak up about your supervisor's actions to their superior," and (2) "You are comfortable speaking up about your supervisor's actions to their superior." Participants indicate their willingness to voice [speak up] using a 7-point scale anchored at "Strongly Disagree" and "Strongly Agree."

\subsubsection{Independent variables}

The independent variables in this model were abusive supervision and a mentoring relationship. Abusive supervision is expected to have a negative effect on the dependent variable voicing. A mentoring relationship is expected to have a positive effect on the dependent variable voicing. Each of these independent variables were operationalized in a quasi-experimental setting. The next section (Section 3.4.2.1.) discusses the abusive supervision conditions used in the vignette in greater detail. Following that, the subsequent section (Section 3.4.2.2.) discusses the mentoring relationship conditions used in the vignette. The complete instrument with all four vignettes is included in Appendix $\mathrm{C}$.

\subsubsection{Abusive supervision}

This study contained two conditions for abusive supervision: (1) high and (2) low. In the high abusive supervisor condition, the supervisor exhibited abusive behaviors as defined by Tepper (2000). The abusive supervision characteristics were adapted from Burton and Hoobler (2006) for the vignette. The following was used in the high abusive supervision condition: 
Your supervisor has a reputation of frequently making negative comments to the team. During your conversation about the possible exposure, with the door to the office open your supervisor becomes visibly upset and yells at you allowing your team to hear. Your supervisor slams the door shut and severely criticizes you saying how it's not your place to try to lead the team and that the expectation in this firm is that supervisors run their teams without interference from associates. It is made clear that behavior like this in the future will not be tolerated and could lead to termination. You attempt to speak, but you are interrupted and told to go back to work.

The following was used in the low abusive supervision condition:

Your supervisor has a reputation of frequently making positive comments to the team. During your conversation about the possible exposure, they immediately become concerned and listen to you closely. You are complimented on your handling of the situation and it's made clear that your actions should be copied by others at the firm.

\subsubsection{Mentoring relationship}

This study contained two conditions for a mentoring relationship: (1) high and (2) low.

In the first condition, the vignette described a mentor that was external to the protégé's supervisory structure and one that exhibited mentoring behaviors as defined by Kram (1988).

The following was the high mentoring relationship condition:

Your firm does not have a formal mentoring system, but you receive mentoring guidance from a supervisor in another division of your firm who went to your university. You get together after work at a variety of social gatherings, which have been very helpful in teaching you the "ins and outs" of the firm. While you do not work directly with one another you routinely interact and discuss strategies to help increase your visibility in the firm and make the best decisions about sensitive issues.

In the condition where there was a low mentoring relationship the following was used:

Your firm does not have a formal mentoring system, but you receive mentoring guidance from a supervisor in another division of your firm who went to your university. You get together after work at a variety of social gatherings and share the same attitude, values, and behaviors. While you do not work directly together, you have become friends. 


\subsubsection{Manipulation checks}

After reading the vignette, two checks provided assurance the participants attended to the conditions. Following previous literature for the abusive supervision conditions, three items were selected from Tepper (2000)'s abusive supervision scale (Burton \& Hoobler, 2006, 344). Those three statements were: (1) "Your supervisor ridicules you," (2) "Your supervisor is rude to you," and (3) Your supervisor puts you down in front of others." To evaluate the mentoring relationship conditions, three items were selected from the Ragins and and McFarlin (1990) mentoring role scale. Those items were: (1) "Your mentor uses influence to support your advancement in the firm," (2) "Your mentor gives you advice on how to attain recognition in the firm," and (3) "You mentor suggests specific strategies for achieving your career aspirations." Participants responded to all six check items using a 7-point scale anchored at "Strongly Disagree" and "Strongly Agree."

\subsection{Participants}

The participants for my study included graduate and undergraduate students at West Virginia University in the College of Business and Economics. This sample was selected to proxy for firm professionals, which is a strategy consistent with prior literature (Kaplan et al., 2010). The participants were enrolled in at least one of the following six programs: (1) Online Master of Business Administration, (2) Master of Business Administration, (3) Master of Industrial Relations, (4) Master of Professional Accountancy, (5) Master of Science in Finance, and (6) Bachelor of Science in Business Administration. ${ }^{33}$ Participants have knowledge of basic financial information some have had exposure to working in firms via internships and prior work experience. Participation in the study was voluntary, although monetary incentives were raffled,

\footnotetext{
${ }^{33}$ Participants from the Bachelor of Science in Business Administration were enrolled in one of two separate undergraduate accounting classes.
} 
which is appropriate for decision performance tasks (Awasthi \& Pratt, 1990). ${ }^{34}$ Demographic information, including age, gender, and work experience was collected to assist in interpretation of the findings.

To determine the appropriate sample size for a study, a power analysis was conducted a priori (Field, 2013, 70; Pedhazer \& Schmelkin, 1991, 339). When employing an analysis of variance (ANOVA), power is based on the number of cells in the study. To determine the sample size four inputs are required: (1) $\alpha$ or the risk of incorrect rejection of the null, (2) $\beta$ or the risk of incorrect acceptance, where power is $1-\beta,(3) r$, the effect size, and (4) the number of tails. ${ }^{35}$ Alpha was set at the traditional level of 0.05 , beta was set at $0.20(1-\beta=$ a power of 0.80$)$, the effect size is $0.30 .{ }^{36}$ A one-tailed test was selected based on the direction of the hypotheses. A conservative estimate of the sample was calculated to be 28 participants per cell $(n=112) .{ }^{37}$

\title{
3.6. Analysis method
}

The effects of the quasi-experimental design for abusive supervision and mentoring relationship and their effects of willingness to voice are evaluated in a 2 (abusive supervision high/low) $\times 2$ (mentor relationship high/low) between subjects factorial analysis of variance (ANOVA). The expected rank order of each cell is presented in Table 8.

\author{
[insert Table 8 here]
}

\footnotetext{
34 Specifically, eight $\$ 25$ gift cards and two \$100 gift cards were raffled to participants who entered their email address at the end of the survey.

${ }^{35}$ Following Field's $(2013,339)$ recommendation, I utilized the G*Power $(2016)$ software package to determine the sample size.

36 The effect size is conservatively set at 0.30 , which was selected based on the effect sizes shown in prior studies for abusive supervision, voicing, and mentoring. The smaller the effect size, the larger the sample must be to detect the desired effect.

${ }^{37}$ After pilot testing, another analysis was conducted with the initial effect size of 0.50 . This calculation indicated 92 participants, 23 per cell, were needed to capture the desired effect size.
} 


\subsubsection{Conditioning variables}

In addition to the primary focus of my study, there are three additional conditioning variables: (1) proactivity, (2) gender, and (3) organizational turnover intentions (OTI). No formal hypotheses are stated. Bateman and Crant (1993) defined proactivity as a personality trait where an individual is "relatively unconstrained by situational forces and who effects situational change." To measure proactivity, a ten-item measure from Batement and Crant (1993) was incorporated into the materials prior to the vignette. One item measures of turnover intentions and gender also were included. All measured variables are listed in Table 9 with a description. The instrument materials are included in Appendix C.

[insert Table 9 here] 


\section{Analysis}

My study investigated one research question: Does a mentoring relationship assist a protégé to voice in an adverse situation with an abusive supervisor? I relied on three formally stated hypotheses: (1) abusive supervision decreases the likelihood a protégé will voice a violation of firm policies and procedures, (2) the existence of a mentoring relationship increases the likelihood a protégé will voice a violation of firm policies and procedures, and (3) the association between voicing and abusive supervision is moderated by the presence of a mentoring relationship, such that the presence of a mentoring relationship increases the likelihood of voicing a violation of firm policies and procedures. In this chapter, I describe the data collection and statistical tests of the three hypotheses. I begin with a discussion of study responses and demographics provided by the participants. Then I continue with the manipulation check tests before concluding with the following three sections: (1) test of hypothesis one, (2) test of hypothesis two, and (3) test of hypothesis three.

\subsection{Responses and demographics}

To investigate how the abusive supervision condition (SUPR) and the mentor relationship condition (MENT) impact a protégé's voicing behaviors (VOICE) when a violation of policies and procedures occurs Additionally, three conditioning variables proactivity (PROACT), gender (GENDER), and organizational turnover intentions (OTI) were measured. This study required participants with a basic knowledge of financial information and entry-level professional work experience. In this section, I describe how the research instrument was administered, the number of usable responses received, demographic information, and the demographic effects on the study variables. 


\subsubsection{Data collection}

The research instrument was administered in three ways: (1) in emails to graduate students, (2) in person during scheduled class time, and (3) a combination of 1 and 2. First, separate emails were sent to master-level graduate students enrolled at West Virginia University's College of Business and Economics. Five graduate programs participated in the study: (1) Online Master of Business Administration, (2) Master of Business Administration, (3) Master of Professional Accountancy, (4) Master of Science in Finance, and (5) Master of Science in Human Resources and Industrial Relations. The Master of Professional Accountancy students received both an email and in-person recruitment. Two undergraduate classes from one undergraduate program participated in the study: (1) Introductory Accounting Systems and (2) Accounting Systems. ${ }^{38}$ Participants in the undergraduate classes were recruited during scheduled class time. All study responses were collected using the survey-software Qualtrics ${ }^{\circledR}$. All participants were randomly assigned to one of the four vignettes.

\subsubsection{Usable responses and demographic data}

A total of 207 responses were collected and 28 (13.53\%) were unusable. All 28 unusable responses failed to complete the vignette portion of the instrument and were discarded. The final sample contained 179 usable responses with a 52.0\% response rate. Following the methodology provided by Field $(2013,339)$, after pilot testing the total required sample was estimated to be 90 participants. ${ }^{39,40}$ The distribution of responses per cell are reported in Table 10. There were at least 44 responses in each cell.

\footnotetext{
38 This sample was a convenience sample.

${ }^{39}$ I used Field's $(2013,339)$ recommendation to estimate the required sample size based on the effects size from a pilot test utilizing the $\mathrm{G}^{*}$ Power (2016) software package.

40 The observed power for the full model was 0.999. The observed power for SUPR was 0.765. The observed power for MENT was 0.237. The observed power for the SUPR×MENT interaction was 0.093.
} 
[insert Table 10 here]

Of the 179 participants in the final sample, 59.8\% ( $n=107)$ had $0-2$ years of work experience while $40.2 \%(n=72)$ had three or more years of work experience. $87.7 \%(n=157)$ of respondents reported having: (1) a four-year degree in progress or (2) a four-year degree. Female respondents accounted for $39.1 \%(n=70)$ of the sample. Most respondents, $63.1 \%$ ( $n=113)$, reported previously witnessing a violation of policies and procedures in the workplace. All demographic information collected for the participants is summarized in Table 11. The average completion time for the instrument was seven minutes. ${ }^{41}$

[insert Table 11 here]

\subsubsection{Demographic effects on variables}

Five continuous variables were measured using participants' responses: (1) VOICE, (2) ABUSE, (3) MRELATE, (4) PROACT, and (5) OTI. A description of each model, manipulation, and conditioning variable is presented in Table 9. T-tests and ANOVAs were used to investigate whether participants' demographics influenced responses. The results are tabulated in Table 12 and Table 13.

Five dichotomous demographics were investigated for their effect on the five measured variables. These demographics represent whether the participant: (1) was male or female, (2) was assigned a mentor when starting at their firm, (3) developed a non-assigned mentor relationship, (4) wanted a mentor, and (5) witnessed a past violation of policies and procedures. The results of individual t-tests in Table 12 revealed four significant results.

[insert Table 12 here]

\footnotetext{
${ }^{41}$ The average completion time for all participants including unusable responses was one hour and thirteen minutes. This time was driven by three participants who did not complete the study but left the browser open.
} 
First, the manipulation check variable ABUSE was significantly different depending on whether the participant was assigned a mentor. Participants who were assigned a mentor had a mean VOICE score of 3.196 while those not assigned a mentor had a VOICE score of 3.898. Second, the conditioning variable PROACT was significantly different based on whether the participant had: (1) developed a non-assigned mentor relationship and (2) witnessed a violation of policies and procedures. Those participants who developed a non-assigned mentor relationship had mean PROACT score of 5.620 compared to 5.383 for those who did not develop a mentor relationship. Participants who witnessed a violation of policies and procedures had a mean PROACT score of 5.658 compared to a score of 5.342 for the group who had not witnessed any violations.

Five categorical demographic variables were investigated for their effect on the five continuous variables. These demographics represent participant: (1) age, (2) class, (3) highest degree attained, (4) years of work experience, and (5) firm size. The results of ANOVAs indicated seven significant results, which are reported in Table 13.

[insert Table 13 here]

Firm size had a significant impact on: (1) MRELATE, (2) ABUSE, and (3) VOICE. This effect was driven by those respondents in firms at the local-level. In those cases, the mean scores of MRELATE, ABUSE, and VOICE were lower than the other groups. VOICE was significant at the $p<0.100$ level (Cohen, 1994). PROACT was significantly increased by respondents who were older, had higher degrees, and had more work experience. Finally, OTI showed a significant difference based on the age of the respondent. However, this effect is driven by those ages 22-30 who had a mean OTI score of 3.66 compared to the average of 4.08. 


\subsection{Manipulation checks}

Two variables, SUPR and MENT, were manipulated in this quasi-experiment. Each manipulation had two levels: high and low. After reading the vignette, respondents answered six statements, three relating to each condition, regarding the abusive supervisor and mentor relationship. Each statement used a 7-point scale anchored from (1) Strongly Disagree to (7) Strongly Agree. For each manipulation, the three items were averaged together to provide an overall composite score. To determine whether the manipulations affected the respondents' perception of abusive supervision and mentor relationship, ANOVA tests were conducted to determine the significance of the manipulation on the composite measure. Details for each manipulation follow.

\subsubsection{Abusive supervision manipulation check}

Using the three items described in Section 3.4.2.3. from Tepper's (2000) abusive supervision scale, I constructed the composite variable, ABUSE, to determine the participants' assessment of the abusive supervisor manipulation. ABUSE was an average of the three SUPR manipulation check items. An ANOVA was used to determine if the SUPR manipulation influenced the participants' mean ABUSE score. ${ }^{42}$ The mean ABUSE response was 3.699 (S.D. $=2.135$ ) on a 7-point scale where 7 was "Strongly Agree." When the sample was divided between the two levels of SUPR, the mean score for the high SUPR condition was 5.300 (S.D. = 1.671); the low SUPR score was 2.115 (S.D. $=1.121)$. The ANOVA test in Table 14 indicates the effect of SUPR is significant $(\mathrm{F}=224.729 ; p<.001) .{ }^{43}$ The manipulation was successful in influencing the participants' mean perception of abusive supervision in the vignette.

\footnotetext{
${ }^{42}$ In general, three assumptions must be met to conduct an ANOVA: (1) independence of conditions, (2) normal distributions of the residuals, and (3) homogeneity of variance. In this case and all others in this study, the assumptions were met.

${ }^{43}$ All individual measures of ABUSE were significant at conventional levels.
} 
[insert Table 14]

\subsubsection{Mentor relationship manipulation check}

Using the three items described in Section 3.4.2.3. from Ragins and McFarlin's (1990) mentor role scale, I constructed the composite variable, MRELATE, to determine the participants' assessment of the MENT manipulation. MRELATE was an average of the three MENT manipulation check items. An ANOVA was used to answer if the MENT manipulation influenced the participants' mean MRELATE score. The mean MENT response was 4.605 (S.D. 1.385) on a 7-point scale where 7 is "Strongly Agree." When the sample was divided between the two levels of MENT, the mean score for the high MENT condition was 4.766 (S.D. = 1.269); the low MENT score was 4.442 (S.D. = 1.481). The ANOVA test in Table 14 indicate the effect of MENT was not significant $(\mathrm{F}=2.477 ; p=0.117) .{ }^{44}$ The manipulation was not successful in influencing the respondents' mean perception of a mentor relationship in the vignette.

\subsection{The dependent variable}

Using the two items described in Section 3.4.1. from Nelson et al. (2016), I constructed the composite variable, VOICE, to determine the overall voicing intentions of the participants. The mean responses of VOICE are reported in Table 15. In untabulated results, the Pearson correlation coefficient for SUPR and VOICE was $-0.174(p=0.020) .{ }^{45}$ This coefficient indicated a negative relationship between the SUPR and VOICE. The result indicates that when SUPR moved from low to high, the VOICE score decreased. The Pearson correlation coefficient for the MENT manipulation and VOICE was $-0.114(p=0.129)$. This coefficient indicated there was not a discernable difference from zero between MENT and VOICE. ${ }^{46}$ The Pearson

\footnotetext{
${ }^{44}$ Two of the individual measures of MENT were not discernable from zero. One measure was significant at the $p<$ 0.100 level.

45 The two individual measures of VOICE were significant at conventional levels.

46 The two individual measures of VOICE were not discernable from zero.
} 
correlation coefficient for PROACT and VOICE was $0.355(p<0.001) .{ }^{47}$ This coefficient indicated a positive relationship between the PROACT and VOICE. As PROACT increased so too did VOICE. The Pearson correlation coefficient for the GENDER variable and VOICE was $0.085(p=0.260) .^{48}$ Finally, the Pearson correlation coefficient for the OTI variable and VOICE is $-0.075(p=0.320){ }^{49}$

[insert Table 15]

\subsection{Test of $\mathrm{HI}$}

H1 stated that abusive supervision decreases the likelihood a protégé will voice a violation of firm policies and procedures. If the independent variable SUPR had a significant impact on the respondent's voicing intentions, H1 would not be rejected. PROACT, OTI, and GENDER also were tested and added as covariates into the model as necessary.

\subsubsection{H1 analysis of covariance}

To determine if VOICE was influenced by SUPR, an analysis of covariance (ANCOVA) test was used. The dependent measure was VOICE and the independent measure was SUPR. Initially, three covariates were included: (1) PROACT, (2) GENDER, and (3) OTI. GENDER and OTI showed no significant influence and were removed from the model. The ANCOVA was used to answer if the SUPR manipulation influenced the respondents' mean VOICE score while controlling for PROACT. As shown in Table 15, Panel A, the mean VOICE score was 5.142 (S.D. = 1.361) on a 7-point scale where 7 was "Strongly Agree." When the sample was divided between the two levels of SUPR, the mean score for the high SUPR condition was 4.904 $($ S.D. $=1.535)$; the low SUPR score was $5.378($ S.D. $=1.125)$. Those results are reported in

\footnotetext{
${ }^{47}$ Individual component measures used to construct VOICE also exhibit significant correlations with PROACT.

${ }^{48}$ Neither individual component measures used to construct VOICE exhibit correlations with GENDER.

${ }^{49}$ Neither individual component measures used to construct VOICE exhibit correlations with OTI.
} 
Table 15, Panel B. The ANCOVA test in Table 16, Panel A indicated the effect of SUPR was significant $(\mathrm{F}=7.173 ; p=0.008)$. H1 was not rejected. ${ }^{50}$

[insert Table 16]

\subsection{Test of $\mathrm{H} 2$}

H2 stated that the existence of a mentoring relationship increases the likelihood a protégé will voice a violation of firm policies and procedures. If MENT had a significant impact on VOICE, H2 would not be rejected. PROACT, OTI, and GENDER also were tested and added as covariates into the model as necessary.

\subsubsection{H2 analysis of covariance}

To determine if VOICE was affected by MENT, an ANCOVA test was used. The dependent measure was VOICE; the independent measure was MENT. Initially, three covariates were included: (1) PROACT, (2) GENDER, and (3) OTI. GENDER and OTI showed no significant influence and were removed from the model. An ANCOVA was used to answer if MENT influenced participants' mean VOICE score while controlling for PROACT. When the sample was divided between the two levels of MENT, the mean VOICE score for the high MENT condition was 4.989 (S.D. = 1.420); the low MENT score was 5.298 (S.D. = 1.287). Those results are reported in Table 15, Panel C. The ANCOVA test indicated the effect of MENT is not significant $(\mathrm{F}=1.425 ; p=0.234)$. The MENT manipulation was not successful in influencing the respondents' mean voicing intentions. $\mathrm{H} 2$ was rejected. ${ }^{51}$ The results for the test of $\mathrm{H} 2$ are presented in Table 16, Panel B.

\footnotetext{
50 The two individual measures of VOICE also were significant at conventional levels.

${ }^{51}$ The two individual measures of VOICE also were not discernable from zero at conventional levels.
} 


\subsection{Test of $\mathrm{H3}$}

H3 stated that the association between voicing and abusive supervision is moderated by the presence of a mentoring relationship, such that the presence of a mentoring relationship increases the likelihood of voicing a violation of firm policies and procedures. If MENT had a significant impact on VOICE when SUPR is high, H3 would not be rejected. In addition to H3, PROACT, OTI and GENDER were tested and added as covariates into the model as necessary.

\subsubsection{H3 analysis of covariance}

To determine if VOICE was affected the interaction between MENT and SUPR, an ANCOVA test was used. The dependent was VOICE. The independent measures were MENT and SUPR. Initially, three covariates are included: (1) PROACT, (2) GENDER, and (3) OTI. GENDER and OTI showed no significant influence and were removed from the model. An ANCOVA was used to answer if the SUPR $\times$ MENT interaction influenced the participants' mean VOICE score. The effect of SUPR $\times$ MENT on VOICE was not significant $(\mathrm{F}=0.588 ; p=$ 0.543). The SUPR $\times$ MENT interaction was not successful in influencing the respondents' mean voicing intentions. SUPR and MENT individually yielded qualitatively similar results to H1 and H2. H3 was rejected..$^{52}$ The ANCOVA results are reported in Table 16, Panel C. ${ }^{53,54}$

\subsection{Summary}

The question this chapter analyzed was as follows: Does a mentoring relationship assist a protégé to voice in an adverse situation with an abusive supervisor? Specifically, three formally stated hypotheses were investigated: (1) abusive supervision decreases the likelihood a protégé

\footnotetext{
${ }^{52}$ The two individual measures of VOICE also were not discernable from zero at conventional levels for the interaction.

${ }^{53}$ Untabulated supplemental analyses that included bootstrapping did not qualitatively alter the results presented.

${ }^{54}$ Using only Online Master of Business Administration participants from the sample indicated a significant MENT influence and MENT $\times$ SUPR interaction on VOICE. However, the SUPR manipulation was not discernable from zero. The results are untabulated.
} 
will voice a violation of firm policies and procedures, (2) the existence of a mentoring relationship increases the likelihood a protégé will voice a violation of firm policies and procedures, and (3) the association between voicing and abusive supervision is moderated by the presence of a mentoring relationship, such that the presence of a mentoring relationship increases the likelihood of voicing a violation of firm policies and procedures. In this chapter, I analytically investigated those three hypotheses. The results indicated H1 was supported while $\mathrm{H} 2$ and $\mathrm{H} 3$ were rejected. In the next chapter, I discuss the implications of my study. 


\section{Discussion and conclusions}

The purpose of this study was to examine the influence of abusive supervision on voicing and whether this result is influenced by a mentor. The genesis for this study came from Mr. Robert Boisjoly's (1993) courageous account of how he voiced opposition to violations in safety protocol before the Space Shuttle Challenger disaster on January 28, 1986. In Accounting Horizons (1993), Mr. Boisjoly provided a firsthand narrative of suppressed voicing among his colleagues in the presence of abusive supervision and enormous public pressure. Fundamentally, Mr. Boisjoly depicted how ignoring the "elephant in the room" (i.e., disregarding a safety protocol for rubber seals in cold temperatures) adversely affected the ability of NASA officials to uphold quality standards and to exercise sound judgment to postpone the launch. In this instance, ignoring the "elephant in the room" led to the tragic deaths of the Challenger crew and a school teacher, Christa McAuliffe.

Similarly, the accounting profession is characterized by high-pressure work environments and a litany of quality standards that must be maintained to uphold the public's trust (Russell et al., 2016). Tepper et al. (2006) showed that the presence of abusive supervision in the workplace can make firms susceptible to negative outcomes (e.g., absenteeism, increased turnover, legal costs, lower organizational commitment). However, in contrast to abusive supervision, a rich literature has shown that mentoring can provide positive outcomes (e.g., increased organizational commitment, job satisfaction, and self-esteem). Mentoring is a unique relationship between a more experienced mentor and a less experienced protégé. Further, a mentor-protégé relationship is one where the mentor provides career and psychosocial support to the protégé. Mr. Boisjoly touched on the importance of creating such relationships that foster support in the workplace. 
Through voicing, an accounting firm's personnel can maintain quality by addressing issues before they become catastrophic.

To study the effect of abusive supervision and mentoring on voicing, I developed three hypotheses. Based on Tepper (2000) and Mackey et al. (2015), I predicted that an abusive supervisor would decrease a protégé's willingness to voice a violation of policies and procedures. A second hypothesis was developed based on Kram (1983) and Dalton et al. (2015). For this hypothesis, I predicted a mentoring relationship would increase voicing by a protégé when there is a violation of policies and procedures. Accordingly, the third hypothesis tested the interaction between abusive supervision and mentoring on voicing. To operationalize the study, I employed a $2 \times 2$ quasi-experiment design by manipulating both an abusive supervisor (high/low) and a mentor relationship (high/low). The dependent variable, voice, was a two-item response measured on a seven-point scale. Four treatment conditions were randomized in a vignette that placed the participants in a firm where a colleague may have exposed client data. Participants consisted of a sample of graduate and undergraduate students who proxied for accountants. Responses were captured through the online software Qualtrics ${ }^{\circledR}$ using both inperson and remote data collection.

Central to the development of the vignette was the AICPA's framework for quality, as outlined in SQCS No. 8 (AICPA, 2012). Specifically, SQCS No. 8 was foundational to providing the proper organizational context for my study. Three key elements from SQCS No. 8 coincide and are relevant to the variables of interest in this study. The first element, engagement performance, described the supervisor's responsibilities in maintaining legal, regulatory, and ethical requirements. A second element, monitoring, addressed how a concern that is voiced should be dealt with internally by the firm. The human resources element required establishing 
competency, capability, and ethics among the firm's personnel. SQCS No. 8 noted that competency, capability, and ethics could be achieved specifically through mentoring.

The primary finding in this study indicated that abusive supervision decreased voicing when there was a potential violation of policies and procedures. This finding is theoretically consistent with the extant literature. Tepper (2000) defined abusive supervision and found negative consequences associated with this construct. In a separate study, Tepper et al. (2006) also highlighted negative economic consequences from abusive supervision of approximately $\$ 23.8$ billion annually in the United States. My findings also are consistent with recent analyses by Mackey et al. (2015). Through a meta-analysis, Mackey et al. (2015) found that the outcomes of abusive supervision were almost entirely negative. In sum, the presence of abusive supervision in accounting firms can have adverse behavioral and economic consequences.

In this study, it was expected that a mentor providing career support would influence a protégé's decision to voice. I did not find evidence that a mentoring relationship affected voicing behavior. Mentoring can provide two basic functions: (1) career support and (2) psychosocial support (Kram, 1983). Dirsmith et al. (2015) also described how mentors assist protégés in navigating difficult situations within public accounting firms. Although the quantitative results of the quasi-experiment provided insignificant results on the effects of mentoring, participants' responses to open-ended questions provided evidence that participants understood the role of a mentor. Responses were consistent with prior work on mentoring both inside and outside the accounting context (i.e., Dirsmith et al., 2015; Kram, 1983). These responses provided affirmation mentors are used as sounding boards, give firm insights, career support, psychosocial support, and guidance in difficult situations. For instance, one participant described a mentor as: 
Someone who takes the time to review my work product when I ask, offers constructive criticism, shares what they have learned from their own experiences and mistakes to help me prevent some of my own, shares their time with me, has an interest in my success...

Taken together, mentor is still a relevant variable to examine in an abusive work environment that is characterized by abusive supervision, despite the nonsignificant findings for my second and third hypotheses.

\subsection{Contributions}

In this study, I contributed to both the accounting and management literatures by demonstrating that abusive supervision lowers voicing, which can compromise quality. Voicing and abusive supervision have not been studied together in the management or accounting literatures. Voicing can lead to increased quality in the firm by providing managers with the knowledge a problem exists. Within the accounting literature, I extend work begun by Nelson et al. (2016) in voicing and Dalton et al. (2015) with respect to abusive supervision by characterizing the direct supervisor as abusive or not-abusive. Uniquely, my study examined how participants responded after a discussion about a potential violation of policies and procedures with an abusive supervisor. Not only is the direct supervisor important to voicing behavior, but I demonstrate the nature of supervision also is relevant and can potentially have an adverse effect on the firm's performance and quality.

I also provide an initial methodological contribution by testing a mentor manipulation on voicing behavior. As noted by Allen et al. (2008) and Scandura and Pelligrini (2010), mentoring research suffers from a lack of experimental methodologies. Although the mentor manipulation did not yield a significant finding in this study, the participants' responses to open-ended questions concerning the role of a mentor provided rich evidence for future research and a clear avenue for methodological improvement. 


\subsection{Limitations}

Three limitations constrain the interpretation of results for this study. The sampling, experimental design, mentor manipulation, and fatigue limit the interpretation of the findings. The first limitation is the sampling used in the study. The participants in this research were all enrolled at a single university and included undergraduate students. While previous research in accounting has used undergraduate students to conduct experiments, many of the participants had not previously developed a mentor relationship in a work setting. ${ }^{55}$

The use of a quasi-experimental design does not provide the level of internal validity a controlled laboratory setting can provide. However, the approach allowed for the engagement of Master of Business Administration participants enrolled in online classes. These participants had greater work experience who would otherwise be inaccessible. This design implementation allows for greater external validity (Aguinis \& Bradley, 2014). The use of a vignette does weaken external validity. By asking participants to make decisions based on a scenario rather than actual circumstances, some realism is lost.

The mentor manipulations treatment did not function as anticipated. This result could be because the manipulation was not strong enough, the manipulation check did not sufficiently capture the effects of the manipulation, or a combination of both. The manipulation used in this study will need to be further investigated and refined to allow for more interpretable results. Future research could consider utilizing the counseling subscale of the mentor role scale to better detect differences in the mentor relationship conditions.k

Finally, 28 participants started the survey but did not finish. There were no differences between groups when dividing groups based on median completion time. However, with 28

\footnotetext{
${ }^{55}$ When comparing results based on whether participants had developed a mentor relationship or not, there were no discernable differences in responses to voicing.
} 
participants beginning but not completing the study, fatigue may have been a factor biasing the responses of the instrument.

\subsection{Suggestions for future research}

From this study, there are several suggestions for future research. Researchers in accounting could further narrow in on the abusive supervision voice relationship. Other factors may mediate or moderate the relationship. For instance, recent management literature suggests that professionals with high self-leadership may be less phased by abusive supervisors (Houghton, Dawley, \& DiLiello, 2012; Mackey et al., 2016). This suggestion can also be applied to the accounting literature allowing future research to consider the moderating effect of self-leadership. Additionally, organizational-professional conflict is a construct that has been tied to reduced organizational commitment and other negative workplace behaviors including organizational turnover intentions in the accounting setting (Brierley, 1998). Future research in accounting could benefit from an investigation into whether the abusive supervision-voicing relationship is mediated by organizational-professional conflict. By reducing abusive supervision in the workplace, firms can limit costs and improve performance. However, researchers could explore how abusive supervision directly impacts firm costs from an archival perspective. By using a multi-method approach, researchers could triangulate the factors associated with voicing, abusive supervision, and mentoring.

Finally, researchers could benefit from an established voicing scale, which would contribute to the accounting, management, and psychology literatures. Along with Nelson et al. (2016) my study furthers voicing in the accounting literature. Most studies in accounting use whistleblowing. By focusing on voicing and developing a validated scale, researchers and practitioners examine how to improve situations before they spiral to a point where 
whistleblowing is needed. Voicing allows researchers to focus on improvements to the firm and firm performance.

\subsection{Conclusion}

Mr. Boisjoly recommended the only way to effectively bring change in the presence violations of policies and procedures was to voice. Mr. Boisjoly's own experience exposed the potential threats when violations to policies and procedures are unaddressed. My study shows that an abusive supervisor decreases voicing in the accounting setting. The finding is theoretically consistent with the existing management literature on both abusive supervision and voicing. This finding contributes to the accounting profession by presenting evidence that accounting firms with abusive supervision can have a detrimental impact to quality.

Through voicing, a firm can maintain quality by addressing issues before they become catastrophic. Thus, by suppressing voicing, abusive supervision places firms at risk unnecessarily. Mr. Boisjoly’s timeless Accounting Horizons (1993) article examined the negative effects violations of policies and procedures can have on quality. Whether in accounting or any other profession, violations of policies and procedures that are unaddressed can have lasting negative consequences. Sometimes even addressing the elephant in the room cannot affect change in the firm. However, as Mr. Boisjoly $(1993,59)$ stated, "Voice is the option chosen by those who are willing to stand up for ethical principals in the belief that change will result." 


\section{References}

Accounting Today. (2016). < http://www.accountingtoday.com/reports-and-rankings/>.

Adams, J. S. (1963). Towards an understanding of inequity. Journal of Abnormal and Social Psychology, 67(5), 422-436.

Aguinis, H., \& Bradley, K. J. (2014). Best practice recommendations for designing and implementing experimental vignette methodology studies. Organizational Research Methods, 17(4), 351-371.

Allen, T. D. (2007). Mentoring relationships from the perspective of the mentor. In B. R. Ragins, \& K. E. Kram (Eds.), The handbook of mentoring at work: Theory, research, and practice (pp. 123-147). Thousand Oaks, CA: Sage Publications, Inc.

Allen, T. D., \& Eby, L. T. (Eds.). (2010). The Blackwell handbook of mentoring: A multiple perspectives approach. West Sussex, UK: Blackwell Publishing Ltd.

Allen, T. D., Eby, L. T., O’Brien, K. E., \& Lentz, E. (2008). The state of mentoring research: A qualitative review of current research methods and future research implications. Journal of Vocational Behavior, 73(3), 343-357.

Allen, T. D., Eby, L. T., Poteet, M. L., Lentz, E., \& Lima, L. (2004). Career benefits associated with mentoring for protégés: A meta-analysis. Journal of Applied Psychology, 89(1), 127.

Allen, T. D., Poteet, M. L., \& Burroughs, S. M. (1997). The mentor's perspective: A qualitative inquiry and future research agenda. Journal of Vocational Behavior, 51(1), 70-89.

American Institute of Certified Public Accountants (AICPA). (2016). AICPA Code of Professional Conduct.

<http://www.aicpa.org/research/standards/codeofconduct/Pages/default.aspx>.

American Institute of Certified Public Accountants (AICPA). (2012). Statement on Quality Control Standards (SQCS No. 8) A firm's system of quality control (redrafted). 〈http://www.aicpa.org/Research/Standards/AuditAttest/Pages/SQCS.aspx>.

American Institute of Certified Public Accountants (AICPA) (1979). Statement on Quality Control Standards (SQCS No. 1) System of quality control for a CPA firm. New York, NY: AICPA.

Arnold, J. L. (1993). Preface to: "Personal integrity and accountability." Accounting Horizons, $7(1), 58$.

Ashkanasy, N. M., Bennett, R. J., \& Martinko, M. J. (2016). Understanding the high performance workplace: Future directions. In N.M Ashanasy, R.J. Bennett, \& M.J. 
Martinko (Eds.), Understanding the high performance workplace: The line between motivation and abuse, (pp. 301-310), New York, NY: Taylor \& Francis.

Awasthi, V., \& Pratt, J. (1990). The effects of monetary incentives on effort and decision performance: The role of cognitive characteristics. The Accounting Review, 65(4), 797811.

Barker, P., Monks, K., \& Buckley, F. (1999). The role of mentoring in the career progression of chartered accountants. The British Accounting Review, 31(3), 297-312.

Bashshur, M. R., \& Oc, B. (2015). When voice matters: A multilevel review of the impact of voice in organizations. Journal of Management, 41(5), 1530-1554.

Bateman, T. S., \& Crant, J. M. (1993). The proactive component of organizational behavior: A measure and correlates. Journal of Organizational Behavior, 14(2), 103-118.

Bies, R. J., \& Moag, J. S. (1986). Interactional justice: Communication criteria of fairness. Research on Negotiation in Organizations, 1(1), 43-55.

Blau, P. M. (1964). Exchange and power in social life. New York, NY: John Wiley \& Sons.

Boisjoly, R. (1987). Ethical decisions: Morton Thiokol and the space shuttle Challenger disaster. In American Society of Mechanical Engineers Winter Annual Meeting, Boston, MA (December), 1-13.

Boisjoly, R. M. (1993). Personal integrity and accountability. Accounting Horizons, 7(1), 59-69.

Breaux, D. M., Perrewé, P. L., Hall, A. T., Frink, D. D., \& Hochwarter, W. A. (2008). Time to try a little tenderness? The detrimental effects of accountability when coupled with abusive supervision. Journal of Leadership \& Organizational Studies, 15(2), 111-122.

Brierley, J.A. (1998). Accountants' organizational-professional conflict: A meta-analysis. Journal of Psychology, 132(3), 291-300.

Burris, E. R., Detert, J. R., \& Chiaburu, D. S. (2008). Quitting before leaving: The mediating effects of psychological attachment and detachment on voice. Journal of Applied Psychology, 93(4), 912-922.

Burton, J. P., \& Hoobler, J. M. (2011). Aggressive reactions to abusive supervision: The role of interactional justice and narcissism. Scandinavian Journal of Psychology, 52(4), 389-398.

Burton, J. P., \& Hoobler, J. M. (2006). Subordinate self-esteem and abusive supervision. Journal of Managerial Issues, 13(3), 340-355. 
Carlson, D. S., Ferguson, M., Perrewé, P. L., \& Whitten, D. (2011). The fallout from abusive supervision: An examination of subordinates and their partners. Personnel Psychology, 64(4), 937-961.

Chan, M. E., \& McAllister, D. J. (2014). Abusive supervision through the lens of employee state paranoia. Academy of Management Review, 39(1), 44-66.

Cohen, J. (1994). The Earth Is Round (p<. 05), American Psychologist, 49(12), 997-1003.

Cook, T. D., \& Campbell, D. T. (1979). Quasi-experimentation: Design and analysis for field settings. Chicago, IL: Rand McNally.

Cropanzano, R., \& Mitchell, M. S. (2005). Social exchange theory: An interdisciplinary review. Journal of Management, 31(6), 874-900.

Dalton, D. W., Davis, A. B., \& Viator, R. E. (2015). The joint effect of unfavorable supervisory feedback environments and external mentoring on job attitudes and job outcomes in the public accounting profession. Behavioral Research in Accounting, 27(2), 53-76.

Dirsmith, M. W., \& Covaleski, M. A. (1985). Informal communications, nonformal communications and mentoring in public accounting firms. Accounting, Organizations and Society, 10(2), 149-169.

Dirsmith, M. W., Covaleski, M. A., \& Samuel, S. (2015). On being professional in the 21st century: An empirically informed essay. Auditing: A Journal of Practice \& Theory, $34(2), 167-200$.

Dougherty, T. W., Turban, D. B., \& Haggard, D. L. (2010). Naturally occurring mentoring relationships involving workplace employees. In T. D. Allen, \& L. T. Eby (Eds.), The Blackwell handbook of mentoring: A multiple perspectives approach (pp. 139-162). West Sussex, UK: Blackwell Publishing Ltd.

Field, A. (2013). Discovering statistics using IBM SPSS statistics. London, UK: Sage Publications Ltd.

Folger, R., \& Cropanzano, R. (2001). Fairness theory: Justice as accountability. In J. Greenberg \& R. Cropanzano (Eds.), Advances in organizational justice (pp. 1-55). Stanford, CA: Stanford University Press.

Gao, J., Greenberg, R., \& Wong-On-Wing, B. (2015). Whistleblowing intentions of lower-level employees: The effect of reporting channel, bystanders, and wrongdoer power status. Journal of Business Ethics, 126(1), 85-99.

G*Power. (2016). < http://www.gpower.hhu.de/en.html>. 
Hall, M., \& Smith, D. (2009). Mentoring and turnover intentions in public accounting firms: A research note. Accounting, Organizations and Society, 34(6-7), 695-704.

Harvey, M., McIntyre, N., Thompson Heames, J., \& Moeller, M. (2009). Mentoring global female managers in the global marketplace: traditional, reverse, and reciprocal mentoring. The International Journal of Human Resource Management, 20(6), 13441361.

Healthy Workplace Bill. (2017). <http://healthyworkplacebill.org/>.

Herbohn, K. (2004). Informal mentoring relationships and the career processes of public accountants. The British Accounting Review, 36(4), 369-393.

Hirschman, A. O., \& Exit, V. (1970). Loyalty. Responses to Decline in Firms, Organizations, and States. Cambridge, Mass: Harvard University Press.

Houghton, J. D., Dawley, D., \& DiLiello, T. C. (2012). The abbreviated self-leadership questionnaire (ASLQ): A more concise measure of self-leadership. International Journal of Leadership Studies, 7(2), 216-232.

Humphrey, S. E. (2011). What does a great meta-analysis look like? Organizational Psychology Review, 1(2), 99-103.

Jensen, C. (1996). No downlink: A dramatic narrative about the Challenger accident and our time. New York, NY: Farrar, Straus \& Giroux.

Joubert, D. (2006). Rarely witnessed behavior marks the predator-prey relationship of a pride of lions and a herd of Cape buffalo on a marshy island in Botswana's Okavango Delta. National Geographic, 210(3), 110.

Kaplan, S. E. (2015). Discussant comment on whistleblowing intentions of lower-level employees: The effect of reporting channel, bystanders, and wrongdoer power status by Jingyu Gao, Robert Greenberg, Bernard Wong-On-Wing. Journal of Business Ethics, 126(1), 101-102.

Kaplan, S. E., Keinath, A. K., \& Walo, J. C. (2001). An examination of perceived barriers to mentoring in public accounting. Behavioral Research in Accounting, 13(1), 195-220.

Kaplan, S. E., Pany, K., Samuels, J. A., \& Zhang, J. (2009). An examination of the effects of procedural safeguards on intentions to anonymously report fraud. Auditing: A Journal of Practice \& Theory, 28(2), 273-288.

Kaplan, S. E., Pope, K. R., \& Samuels, J. A. (2010). The effect of social confrontation on individuals' intentions to internally report fraud. Behavioral Research in Accounting, 22(2), 51-67. 
Klaussner, S. (2014). Engulfed in the abyss: The emergence of abusive supervision as an escalating process of supervisor-subordinate interaction. Human Relations, 67(3), 311332.

Kram, K. E. (1983). Phases of the mentor relationship. Academy of Management Journal, 26(4), 608-625.

Kram, K. E. (1988). Mentoring at work: Developmental relationships in organizational life. Lanham, MD: University Press of America, Inc.

Kram, K. E., \& Ragins, B. R. (2007). The landscape of mentoring in the 21 st century. In B. R. Ragins, \& K. E. Kram (Eds.), The handbook of mentoring at work: Theory, research, and practice (pp. 659-692). Thousand Oaks, CA: Sage Publications, Inc.

Largay III, J. A. (2002). Lessons from Enron. Accounting Horizons, 16(2), 153-156.

Liang, J., Farh, C. I., \& Farh, J. L. (2012). Psychological antecedents of promotive and prohibitive voice: A two-wave examination. Academy of Management Journal, 55(1), 7192.

Mackey, J. D., Frieder, R. E., Brees, J. R., \& Martinko, M. J. (2015). Abusive supervision: A meta-analysis and empirical review. Journal of Management, doi: 0149206315573997.

Martin, D., \& Yee, M. K. (2012). Roger Boisjoly, 73, Dies; Warned of Shuttle Danger. New York Times, 3.

Martinko, M. J., Harvey, P., Brees, J. R., \& Mackey, J. (2013). A review of abusive supervision research. Journal of Organizational Behavior, 34(S1), S120-S137.

Mawritz, M. B., Mayer, D. M., Hoobler, J. M., Wayne, S. J., \& Marinova, S. V. (2012). A trickle-down model of abusive supervision. Personnel Psychology, 65(2), 325-357.

Mesmer-Magnus, J. R., \& Viswesvaran, C. (2005). Whistleblowing in organizations: An examination of correlates of whistleblowing intentions, actions, and retaliation. Journal of Business Ethics, 62(3), 277-297.

Mintz, S. (2016). Giving voice to values: A new approach to accounting ethics education. Global Perspectives on Accounting Education, 13(1), 37-50

Moberly, R. (2006). Sarbanes-Oxley's structural model to encourage corporate whistleblowers. Brigham Young University Law Review, 2006(5) 1107-1180.

Nader, R., Petkas, P. J., \& Blackwell, K. (Eds.). (1972). Whistle blowing: The report of the conference on professional responsibility (pp. 39-146). New York, NY: Grossman Publishers. 
Namie, G., \& Namie, R. (2000). Workplace bullying: The silent epidemic. Employee Rights Quarterly, 1(2), 1-12.

National Aeronautics Space Administration. (NASA). (2001). Apollo-13. $<$ http://science.ksc.nasa.gov/history/apollo/apollo-13/apollo-13.html>.

Near, J. P., \& Miceli, M. P. (1985). Organizational dissidence: The case of whistle-blowing. Journal of Business Ethics, 4(1), 1-16.

Nelson, M. W., Proell, C. A., \& Randel, A. E. (2016). Team-oriented leadership and auditors' willingness to raise audit issues. The Accounting Review, 9(6), 1781-1805.

Olian, J. D., Carroll, S. J., \& Giannantonio, C. M. (1993). Mentor reactions to protégés: An experiment with managers. Journal of Vocational Behavior, 43(3), 266-278.

Olian, J. D., Carroll, S. J., Giannantonio, C. M., \& Feren, D. B. (1988). What do protégés look for in a mentor? Results of three experimental studies. Journal of Vocational Behavior, $33(1), 15-37$.

Parker, E. (2012). Accounting Firms/CPAs. <http://www.aicpa.org/interestareas/forensicand valuation/membership/downloadabledocuments/accounting-firmscpas.pdf $>$.

Parmerlee, M. A., Near, J. P., \& Jensen, T. C. (1982). Correlates of whistle-blowers' perceptions of organizational retaliation. Administrative Science Quarterly, 27(1), 17-34.

Pausch, R. 2007. Randy Pausch's last lecture: Really achieving your childhood dreams. The Last Lecture. 〈http://www.youtube.com/watch?v=ji5_MqicxSo〉.

Payne, S. C., \& Huffman, A. H. (2005). A longitudinal examination of the influence of mentoring on organizational commitment and turnover. Academy of Management Journal, 48(1), 158-168.

Pedhazur, E. J. \& Schmelkin, LP (1991). Measurement, design, and analysis: An integrated approach. New York, NY: Psychology Press.

Pichler, S., Livingston, B. A., Ruggs, E. N., \& Varma, A. (2016). The dark side of high performance worksystems. In N.M Ashanasy, R.J. Bennett, \& M.J. Martinko (Eds.), Understanding the high performance workplace: The line between motivation and abuse, (pp. 231-251), New York, NY: Taylor \& Francis.

Power, R. J., \& Compion, R. X. S. (2009). Lion predation on elephants in the Savuti, Chobe national park, Botswana. African Zoology, 44(1), 36-44.

Ragins, B. R., \& Kram, K. E. (Eds.). (2007). The handbook of mentoring at work: Theory, research, and practice. Thousand Oaks, CA: Sage Publications, Inc. 
Ragins, B. R., \& McFarlin, D. B. (1990). Perceptions of mentor roles in cross-gender mentoring relationships. Journal of Vocational Behavior, 37(3), 321-339.

Rehg, M. T., Miceli, M. P., Near, J. P., \& Van Scotter, J. R. (2008). Antecedents and outcomes of retaliation against whistleblowers: Gender differences and power relationships. Organization Science, 19(2), 221-240.

Reinstein, A. \& Apostolou, B. (2015). A step up in standards for peer reviewers. Journal of Accountancy, 220(6), 54-58.

Rest, J. R. (1986). Moral development: Advances in research and theory. New York, NY: Praeger Publishers.

Russell, Z. A., Ferris, G. R., \& Sikora, D. M. (2016). Crossing the line between high performance work practices and abusive supervision. In N.M Ashanasy, R.J. Bennett, \& M.J. Martinko (Eds.), Understanding the high performance workplace: The line between motivation and abuse, (pp. 126-145), New York, NY: Taylor \& Francis.

Scandura, T. A., \& Pellegrini, E. K. (2010). Workplace mentoring: Theoretical approaches and methodological issues. In T. D. Allen, \& L. T. Eby (Eds.), The Blackwell handbook of mentoring: A multiple perspectives approach (pp. 71-91). West Sussex, UK: Blackwell Publishing Ltd.

Sheehan, M., McCarthy, P., Barker, M., \& Henderson, M. (2001). A model for assessing the impacts and costs of workplace bullying, paper presented at the Standing Conference on Organizational Symbolism (SCOS), 30 June-4 July 2001. Dublin, Trinity College.

Seifert, D. L., Sweeney, J. T., Joireman, J., \& Thornton, J. M. (2010). The influence of organizational justice on accountant whistleblowing. Accounting, Organizations and Society, 35(7), 707-717.

Siegel Christian, J., Christian, M. S., Garza, A. S., \& Ellis, A. P. (2012). Examining retaliatory responses to justice violations and recovery attempts in teams. Journal of Applied Psychology, 97(6), 1218.

Siegel, P. H., Reinstein, A., \& Miller, C. L. (2001). Mentoring and organization justice among audit professionals. Journal of Accounting, Auditing \& Finance, 16(1), 1-25.

Sorensen, J. E., \& Sorensen, T. L. (1974). The conflict of professionals in bureaucratic organizations. Administrative Science Quarterly, 19(1), 98-106.

Taylor, E. Z., \& Curtis, M. B. (2016). Mentoring: A Path to Prosocial Behavior. Journal of Business Ethics, doi: 10.1007/s10551-016-3325-1

Taylor, E. Z., \& Curtis, M. B. (2013). Whistleblowing in audit firms: Organizational response and power distance. Behavioral Research in Accounting, 25(2), 21-43. 
Tepper, B. J. (2007). Abusive supervision in work organizations: Review, synthesis, and research agenda. Journal of Management, 33(3), 261-289.

Tepper, B. J. (2000). Consequences of abusive supervision. Academy of Management Journal, 43(2), 178-190.

Tepper, B. J., Duffy, M. K., Henle, C. A., \& Lambert, L. S. (2006). Procedural injustice, victim precipitation, and abusive supervision. Personnel Psychology, 59(1), 101-123.

Tepper, B. J., Duffy, M. K., \& Shaw, J. D. (2001). Personality moderators of the relationship between abusive supervision and subordinates' resistance. Journal of Applied Psychology, 86(5), 974-983.

Viator, R. E. (1999). An analysis of formal mentoring programs and perceived barriers to obtaining a mentor at large public accounting firms. Accounting Horizons, 13(1), 37-53.

Viator, R. E. (2001). The association of formal and informal public accounting mentoring with role stress and related job outcomes. Accounting, Organizations and Society, 26(1), 7393.

Viator, R. E., \& Pasewark, W. R. (2005). Mentorship separation tension in the accounting profession: The consequences of delayed structural separation. Accounting, Organizations and Society, 30(4), 371-287. 


\section{Appendix A - Tables}

\section{Table 1}

Elements of Statement on Quality Control Standard (SQCS) No. 8.

SQCS No. 8 element Brief description

1. Engagement Ensure consistency, supervision responsibilities, and review performance responsibilities. When difficult issues arise, consultations occur and are documented. Quality control reviews should occur according to policies and procedures.

2. Ethical requirements

The AICPA's Code of Professional Conduct (AICPA, 2016a) is reinforced through leadership, training, monitoring, and dealing with noncompliance. Independence is always key.

3. Human resources

Maintain sufficient personnel levels. Ensuring personnel has competence, capabilities, and commitment. Ensuring those abilities increase for personnel as the move up within the firm. Increase abilities through education, training, experience, and mentoring.

4. Leadership

Promote an internal culture that quality is essential. Leaders assume the ultimate responsibility.

5. Monitoring Assess and remediate deficiencies. Provide reasonable assurance that complaints and allegations are dealt with appropriately.

6. Relationships To accept or continue a relationship firms much be competent in the area, comply with all ethical requirements, and consider client integrity.

Source: AICPA (2012) 
Table 2

Summary of relevant abusive supervision literature.

\begin{tabular}{|c|c|c|c|c|}
\hline Reference & Method & $\begin{array}{l}\text { Research } \\
\text { design }\end{array}$ & Sample & Key findings \\
\hline Tepper (2000) & $S$ & $\begin{array}{l}\text { Perception of } \\
\text { abusive } \\
\text { supervision at } \\
\text { two time points }\end{array}$ & $\begin{array}{l}\text { Residents of a medium- } \\
\text { sized Midwestern city. } \\
\text { T1 } n=712,53.0 \% \\
\text { response rate; T2 } \\
n=362 ; 50.8 \% \text { response } \\
\text { rate }\end{array}$ & $\begin{array}{l}\text { Defines the abusive supervision construct, develops a } \\
\text { measure, and examines its consequences. Findings indicate } \\
\text { the abusive supervision leads to dysfunctional consequences, } \\
\text { experiences with injustice affect reactions to abusive } \\
\text { supervision, and consequences are more prominent for those } \\
\text { with less job mobility. }\end{array}$ \\
\hline $\begin{array}{l}\text { Tepper et al. } \\
(2006)\end{array}$ & $\mathrm{S}$ & $\begin{array}{l}\text { Field survey of } \\
\text { both } \\
\text { supervisors and } \\
\text { subordinate } \\
\text { perceptions. }\end{array}$ & $\begin{array}{l}\text { National Guard } \\
\text { members and military } \\
\text { supervisors } 334 \text { dyads }\end{array}$ & $\begin{array}{l}\text { Supervisors' depression mediates the relationship between } \\
\text { procedural justice and the subordinates' perceptions of } \\
\text { abusive supervision. Between } 10 \%-16 \% \text { of employees are } \\
\text { subjected to abusive supervision at a cost of } \$ 17,000-\$ 24,000 \\
\text { per serious incident through absenteeism, legal costs, reducec } \\
\text { productivity, and turnover. } \$ 23.8 \text { billion annually in the U.S }\end{array}$ \\
\hline Tepper (2007) & $\mathrm{R}$ & $\begin{array}{l}\text { Analysis of } \\
\text { abusive } \\
\text { supervision }\end{array}$ & $\begin{array}{l}\text { All abusive supervision } \\
\text { literature from 2000- } \\
2007\end{array}$ & $\begin{array}{l}\text { Provides an initial review of the abusive supervision } \\
\text { construct including antecedents and consequences. } \\
\text { Additionally, the review offers an emergent research model } \\
\text { based on abusive supervision studies. }\end{array}$ \\
\hline $\begin{array}{l}\text { Mawritz et al. } \\
(2012)\end{array}$ & $\mathrm{S}$ & $\begin{array}{l}\text { Measures } \\
\text { perceptions of } \\
\text { abusive } \\
\text { supervision, } \\
\text { hostile work } \\
\text { climate }\end{array}$ & $\begin{array}{l}\text { U.S. employees working } \\
\text { more than } 20 \text { hours per } \\
\text { week ( } n=383 \text { work } \\
\text { pairs; } 75.2 \% \text { response } \\
\text { rate) }\end{array}$ & $\begin{array}{l}\text { Abusive supervision has a trickledown effect from managers } \\
\text { to supervisors to employees. The results are exacerbated } \\
\text { when there is a higher hostile workplace climate. }\end{array}$ \\
\hline $\begin{array}{l}\text { Martinko et al. } \\
\text { (2013) }\end{array}$ & $\mathrm{R}$ & $\begin{array}{l}\text { Analysis of } \\
\text { abusive } \\
\text { supervision }\end{array}$ & $\begin{array}{l}\text { Research focused from } \\
2008-2012 \text { with a brief } \\
\text { overview of } 2000-2007\end{array}$ & $\begin{array}{l}\text { Reviews abusive supervision literature from } 2008-2012 \text {, } \\
\text { Tepper's (2007) model, and distinguishes between abusive } \\
\text { supervisory perceptions and abusive supervisory behavior. }\end{array}$ \\
\hline
\end{tabular}




\begin{tabular}{|c|c|c|c|c|}
\hline Reference & Method & $\begin{array}{l}\text { Research } \\
\text { design }\end{array}$ & Sample & Key findings \\
\hline $\begin{array}{l}\text { Mackey et al. } \\
(2015)\end{array}$ & M & $\begin{array}{l}\text { Statistical } \\
\text { analysis of the } \\
\text { correlates to } \\
\text { abusive } \\
\text { supervision }\end{array}$ & $\begin{array}{l}112 \text { studies with } 140 \\
\text { independent samples } \\
\text { investigating the abusive } \\
\text { supervision construct }\end{array}$ & $\begin{array}{l}\text { Indicates that abusive supervision is almost universally } \\
\text { negative. The authors suggest examining abusive supervision } \\
\text { in other contexts to fully understand the construct. }\end{array}$ \\
\hline
\end{tabular}

$\mathrm{M}=$ meta-analysis, $\mathrm{R}=$ review, $\mathrm{S}=$ survey. 


\section{Table 3}

Outcomes of abusive supervision.

\begin{tabular}{lll}
\hline Outcome & Definition & Reference \\
\hline $\begin{array}{l}\text { Emotional } \\
\text { exhaustion }\end{array}$ & $\begin{array}{l}\text { Emotional and physical strain } \\
\text { resulting from stressors in the } \\
\text { workplace characterized as lack } \\
\text { of energy and a feeling that } \\
\text { one's emotional resources are } \\
\text { used up. }\end{array}$ & \\
& $\begin{array}{l}\text { Any form of behavior that is } \\
\text { intended to harm employees of } \\
\text { an organization or the }\end{array}$ & \\
Workplace & Burton \& Hoobler $(2011,390)$ \\
aggression & $\begin{array}{l}\text { The degree of satisfaction with } \\
\text { one's family of origin and the } \\
\text { constituent relationships that } \\
\text { are imbedded. }\end{array}$ & \\
& Carlson et al. $(2011,941)$ \\
& $\begin{array}{l}\text { Non-conformance to a } \\
\text { supervisor's attempts at } \\
\text { influence. }\end{array}$ & \\
\hline
\end{tabular}

Source: Martinko et al. (2013) 
Table 4

Summary of relevant voicing literature.

\begin{tabular}{|c|c|c|c|c|}
\hline Reference & Method & $\begin{array}{l}\text { Research } \\
\text { design }\end{array}$ & Sample & Contribution \\
\hline $\begin{array}{l}\text { Hirschman } \\
(1970)\end{array}$ & $\mathrm{C}$ & & Anecdotal evidence & Introduced and defined the concepts exit, voice, and loyalty. \\
\hline $\begin{array}{l}\text { Nader et al. } \\
(1972)\end{array}$ & $\mathrm{C}$ & $\begin{array}{l}\text { Collection of } \\
\text { whistleblowing } \\
\text { accounts }\end{array}$ & Anecdotal evidence & Introduced whistleblowing to a mass audience. \\
\hline $\begin{array}{l}\text { Parmerlee et } \\
\text { al. (1982) }\end{array}$ & $\mathrm{S}$ & $\begin{array}{l}\text { Respondents } \\
\text { described the } \\
\text { circumstances, } \\
\text { resolution, and } \\
\text { reactions of } \\
\text { organizations }\end{array}$ & $\begin{array}{l}\text { Women who filed a } \\
\text { complaint with the } \\
\text { Wisconsin Equal Rights } \\
\text { Division ( } n=73 ; 50 \% \\
\text { response rate) }\end{array}$ & $\begin{array}{l}\text { Studied whistleblowing correlates establishing retaliation was } \\
\text { more likely for those respondents more valued by the } \\
\text { organization (e.g., age, experience, education) and those who } \\
\text { lacked public support. }\end{array}$ \\
\hline $\begin{array}{l}\text { Near \& Miceli } \\
(1985)\end{array}$ & $\mathrm{C}$ & $\begin{array}{l}\text { Evaluation of } \\
\text { the } \\
\text { whistleblowing } \\
\text { process }\end{array}$ & Anecdotal evidence & $\begin{array}{l}\text { Established the academic definition of whistleblowing by } \\
\text { developing a model of the whistleblowing process. }\end{array}$ \\
\hline Arnold (1993) & $\mathrm{C}$ & $\begin{array}{l}\text { Introduction of } \\
\text { Robert Boisjoly } \\
\text { to the } \\
\text { accounting } \\
\text { literature }\end{array}$ & Anecdotal evidence & $\begin{array}{l}\text { Introduce Robert Boisjoly and offer commentary to the } \\
\text { necessity of Boisjoly (1993). }\end{array}$ \\
\hline $\begin{array}{l}\text { Boisjoly } \\
(1993)\end{array}$ & $\mathrm{C}$ & $\begin{array}{l}\text { Evaluate the } \\
\text { Challenger } \\
\text { launch decision } \\
\text { and subsequent } \\
\text { investigation }\end{array}$ & Anecdotal evidence & $\begin{array}{l}\text { Introduced exit, voice, and loyalty to the accounting literature } \\
\text { with a firsthand narrative. }\end{array}$ \\
\hline
\end{tabular}




\begin{tabular}{|c|c|c|c|c|}
\hline Reference & Method & $\begin{array}{l}\text { Research } \\
\text { design }\end{array}$ & Sample & Contribution \\
\hline $\begin{array}{l}\text { Mesmer- } \\
\text { Magnus \& } \\
\text { Viswesvaran, } \\
2005\end{array}$ & M & $\begin{array}{l}\text { A statistical } \\
\text { analysis of the } \\
\text { correlates of } \\
\text { whistleblowing }\end{array}$ & $\begin{array}{l}21 \text { studies with } 26 \\
\text { independent samples } \\
\text { investigating } \\
\text { whistleblowing }\end{array}$ & $\begin{array}{l}\text { Conduct a meta-analysis of whistleblower characteristics, } \\
\text { whistleblowing correlates, and retaliation characteristics. }\end{array}$ \\
\hline $\begin{array}{l}\text { Rehg et al., } \\
(2008)\end{array}$ & $\mathrm{S}$ & $\begin{array}{l}\text { A survey that } \\
\text { focused on } \\
\text { retaliation after } \\
\text { whistleblowing }\end{array}$ & $\begin{array}{l}\text { Air Force civilian } \\
\text { employees and active- } \\
\text { duty military }(n=3,288 \text {; } \\
33.2 \% \text { response rate })\end{array}$ & $\begin{array}{l}\text { Females perceived greater retaliation; low power and lack of } \\
\text { support were also associated with greater perceived } \\
\text { retaliation. Retaliation was negatively related to the } \\
\text { subordinates' relationship with the supervisor. }\end{array}$ \\
\hline $\begin{array}{l}\text { Kaplan et al., } \\
(2010)\end{array}$ & $\mathrm{E}$ & $\begin{array}{l}\text { A } 2 \times 2 \\
\text { experiment } \\
\text { where fraud } \\
\text { type and social } \\
\text { confrontation } \\
\text { are manipulated }\end{array}$ & $\begin{array}{l}\text { MBA students }(n=96) \\
\text { completed the } \\
\text { instrument with } 77 \\
\text { correctly responding to } \\
\text { the manipulation checks }\end{array}$ & $\begin{array}{l}\text { Employees experiencing an unsuccessful social confrontation } \\
\text { are more likely to seek out powerful internal report recipients } \\
\text { (supervisor's supervisor rather than an internal auditor). The } \\
\text { type of fraud did not influence the participants' intentions to } \\
\text { report. }\end{array}$ \\
\hline $\begin{array}{l}\text { Seifert et al., } \\
(2010)\end{array}$ & $\mathrm{E}$ & $\begin{array}{l}\text { A } 2 \times 2 \times 2 \\
\text { experiment } \\
\text { manipulating } \\
\text { procedures, } \\
\text { management } \\
\text { interactions, } \\
\text { and outcomes }\end{array}$ & $\begin{array}{l}\text { Subjects were internal } \\
\text { auditors or management } \\
\text { accountants }(n=447 ; \\
16.7 \% \text { response rate })\end{array}$ & $\begin{array}{l}\text { Found whistleblowing policies and mechanisms } \\
\text { incorporating higher levels of procedural, distributive, and } \\
\text { interactional justice were perceived to increase the likelihood } \\
\text { that an accountant would internally report a financial } \\
\text { statement fraud. }\end{array}$ \\
\hline $\begin{array}{l}\text { Bashshur \& Oc } \\
(2015)\end{array}$ & $\mathrm{R}$ & $\begin{array}{l}\text { Analysis of the } \\
\text { voicing } \\
\text { literature }\end{array}$ & $\begin{array}{l}\text { A review of the } \\
\text { theoretical framework of } \\
\text { voicing }\end{array}$ & $\begin{array}{l}\text { Discuss the definition and development of the voice } \\
\text { construct. Discussion includes the outcomes, mediators, } \\
\text { moderators, and future research, which should address a need } \\
\text { for more context. }\end{array}$ \\
\hline
\end{tabular}




\begin{tabular}{|c|c|c|c|c|}
\hline Reference & Method & $\begin{array}{l}\text { Research } \\
\text { design }\end{array}$ & Sample & Contribution \\
\hline $\begin{array}{l}\text { Gao et al. } \\
(2015)\end{array}$ & $\mathrm{E}$ & $\begin{array}{l}\text { A } 2 \times 2 \times 2 \times 2 \\
\text { experiment } \\
\text { manipulating } \\
\text { reporting } \\
\text { channel, } \\
\text { bystander, } \\
\text { power status, } \\
\text { and case }\end{array}$ & $\begin{array}{l}\text { U.S. business students } \\
(n=369) \text { proxy for } \\
\text { lower-level employees }\end{array}$ & $\begin{array}{l}\text { The presence of bystanders reduces the likelihood of the } \\
\text { intent to whistleblow. An external reporting channel reduces } \\
\text { the bystander effect. }\end{array}$ \\
\hline $\begin{array}{l}\text { Nelson et al. } \\
(2016)\end{array}$ & $\mathrm{E}$ & $\begin{array}{l}5 \text { studies. } 1 \\
\text { survey and } 4 \\
\text { experiments } \\
\text { using both } \\
\text { between- } \\
\text { subjects and } \\
\text { within-subjects } \\
\text { designs }\end{array}$ & $\begin{array}{l}\text { Audit staff from two } \\
\text { large public accounting } \\
\text { firms. S1 } n=197,53.0 \% \\
\text { response rate; E1 } \\
n=114 \text {; E2 } n=31 \text {; E3 } \\
n=41 \text {; E4 } n=114\end{array}$ & $\begin{array}{l}\text { First to examine employee voice in the accounting literature. } \\
\text { Auditors' willingness to address audit issues is affected by } \\
\text { how they think their message will be received. } \\
\text { Consequences were not attributable to willingness to speak } \\
\text { up. }\end{array}$ \\
\hline
\end{tabular}

$\mathrm{C}=$ commentary, $\mathrm{E}=$ experimental, $\mathrm{M}=$ meta-analysis, $\mathrm{R}=$ review, $\mathrm{S}=$ survey. 
Table 5

Summary of relevant mentoring literature.

\begin{tabular}{|c|c|c|c|c|}
\hline Reference & Method & Research design & Sample & Contribution \\
\hline Kram (1983) & CA & $\begin{array}{l}\text { Two separate } \\
\text { interviews with } \\
\text { protégés their } \\
\text { identified } \\
\text { mentors }\end{array}$ & $\begin{array}{l}18 \text { pairs of } \\
\text { mentors/protégés from a } \\
\text { northeastern public } \\
\text { utility }\end{array}$ & $\begin{array}{l}\text { Identifies how a mentor/protégé relationship progresses } \\
\text { through several phases in both career and psychosocial } \\
\text { functions. }\end{array}$ \\
\hline Kram (1988) & $\mathrm{C}$ & & & Discusses the mentor/protégé relationship in organizations. \\
\hline $\begin{array}{l}\text { Olian et al. } \\
\text { (1988) }\end{array}$ & $\mathrm{E}$ & $\begin{array}{l}\text { Three between- } \\
\text { subject } \\
\text { experiments } \\
\text { manipulating } \\
\text { mentor } \\
\text { interpersonal } \\
\text { competence, } \\
\text { gender, age, } \\
\text { and } \\
\text { organizational } \\
\text { network }\end{array}$ & $\begin{array}{l}\text { Undergraduate students } \\
\mathrm{E} 1 n=167 ; \mathrm{E} 2 n=271 ; \mathrm{E} 3 \\
n=238\end{array}$ & $\begin{array}{l}\text { Examine the protégé attraction to a mentor relationship. The } \\
\text { findings indicate the mentor's interpersonal competence } \\
\text { influences protégé attraction. The mentor's work experience, } \\
\text { age, and gender did not have a consistent influence across the } \\
\text { studies. }\end{array}$ \\
\hline $\begin{array}{l}\text { Olian et al. } \\
\text { (1993) }\end{array}$ & $\mathrm{E}$ & $\begin{array}{l}\text { A } 2 \times 2 \times 2 \times 2 \\
\text { experiment } \\
\text { manipulating } \\
\text { protégé } \\
\text { performance, } \\
\text { gender, marital } \\
\text { status, and } \\
\text { mentor gender }\end{array}$ & $\begin{array}{l}145 \text { banking industry } \\
\text { managers }\end{array}$ & $\begin{array}{l}\text { Examine the mentor/protégé relationship from the mentor's } \\
\text { perspective. Mentors expected greater rewards when the } \\
\text { protégé had better past performance and were more willing to } \\
\text { mentor when (1) males protégés were married and (2) female } \\
\text { protégés were single. }\end{array}$ \\
\hline
\end{tabular}




\begin{tabular}{|c|c|c|c|c|}
\hline Reference & Method & Research design & Sample & Contribution \\
\hline Viator (1999) & $S$ & $\begin{array}{l}\text { Survey of } \\
\text { barriers to } \\
\text { obtaining a } \\
\text { mentor, mentor } \\
\text { demographics, } \\
\text { formal } \\
\text { mentorship, and } \\
\text { turnover } \\
\text { intentions }\end{array}$ & $\begin{array}{l}\text { CPAs in large public } \\
\text { accounting firms } \\
(n=723 ; 24.1 \% \text { response } \\
\text { rate })\end{array}$ & $\begin{array}{l}\text { Examines protégé's barriers to obtaining a mentor in an } \\
\text { accounting context finding when the mentor and protégé had } \\
\text { no input in the pairing decision, satisfaction was lower. }\end{array}$ \\
\hline Viator (2001) & S & $\begin{array}{l}\text { Survey } \\
\text { examining } \\
\text { formal and } \\
\text { informal } \\
\text { mentoring }\end{array}$ & $\begin{array}{l}\text { CPAs in large public } \\
\text { accounting firms } \\
(n=794 ; 26.5 \% \text { response } \\
\text { rate })\end{array}$ & $\begin{array}{l}\text { Establishes that informal mentoring is associated with reduced } \\
\text { role ambiguity. Informal mentoring relationships are likely to } \\
\text { have stronger bonding and commitment when compared to } \\
\text { formal mentors. }\end{array}$ \\
\hline $\begin{array}{l}\text { Payne \& } \\
\text { Huffman } \\
(2005)\end{array}$ & $S$ & $\begin{array}{l}\text { Survey } \\
\text { examining how } \\
\text { mentors affect } \\
\text { protégés } \\
\text { commitment } \\
\text { over two time } \\
\text { periods }\end{array}$ & $\begin{array}{l}\text { US Army officers. Two } \\
\text { time periods }(n=1,334 ; \\
63 \% \text { response rate; } 51 \% \\
\text { response rate) }\end{array}$ & $\begin{array}{l}\text { Establishes that formal mentors increase a protégé's affective } \\
\text { commitment to the organization. Protégés have higher levels } \\
\text { of commitment one year after being mentored. The type of } \\
\text { mentoring relationship influences affective commitment and } \\
\text { role ambiguity. }\end{array}$ \\
\hline
\end{tabular}




\begin{tabular}{|c|c|c|c|c|}
\hline Reference & Method & Research design & Sample & Contribution \\
\hline $\begin{array}{l}\text { Viator \& } \\
\text { Pasework } \\
(2005)\end{array}$ & $\mathrm{S}$ & $\begin{array}{l}\text { Survey to } \\
\text { examine how } \\
\text { structural } \\
\text { separation of } \\
\text { the } \\
\text { mentor/protégé } \\
\text { relationship }\end{array}$ & $\begin{array}{l}\text { CPAs likely to have } \\
\text { prior mentoring } \\
\text { relationships }(n=707 \text {; } \\
38.0 \% \text { response rate })\end{array}$ & $\begin{array}{l}\text { Both modern and Greco-Roman models of mentoring exist in } \\
\text { accounting. Finds increased levels of mentor tension post- } \\
\text { formal mentor relationship especially when both remain in the } \\
\text { same organization. }\end{array}$ \\
\hline $\begin{array}{l}\text { Dalton et al. } \\
(2015)\end{array}$ & $\mathrm{S}$ & $\begin{array}{l}\text { Survey to } \\
\text { examine how } \\
\text { unfavorable } \\
\text { supervisory } \\
\text { feedback affects } \\
\text { accountants }\end{array}$ & $\begin{array}{l}\text { CPAs employed at large } \\
\text { public accounting firms } \\
(n=421 ; 17.9 \% \text { response } \\
\text { rate })\end{array}$ & $\begin{array}{l}\text { Find that mentors reduce the negative effects of unfavorable } \\
\text { supervisory feedback (USF) for protégés. USF is associated } \\
\text { with lower job satisfaction and role clarity, which is associated } \\
\text { with lower organizational commitment and higher turnover } \\
\text { intentions. }\end{array}$ \\
\hline $\begin{array}{l}\text { Dirsmith et al. } \\
\text { (2015) }\end{array}$ & $\mathrm{C} / \mathrm{R}$ & $\begin{array}{l}\text { Analysis of } \\
\text { qualitative } \\
\text { research } \\
\text { methods in } \\
\text { accounting }\end{array}$ & $\begin{array}{l}\text { Exploration of } \\
\text { qualitative research } \\
\text { through the past } 30 \text { years } \\
\text { in accounting }\end{array}$ & $\begin{array}{l}\text { Discuss the mutual benefits and costs of the mentor/protégé } \\
\text { pair. }\end{array}$ \\
\hline $\begin{array}{l}\text { Taylor \& } \\
\text { Curtis }(2016)\end{array}$ & $\mathrm{S}$ & $\begin{array}{l}\text { Survey to } \\
\text { examine } \\
\text { mentoring and } \\
\text { whistleblowing }\end{array}$ & $\begin{array}{l}\text { US public accountants } \\
(n=120)\end{array}$ & $\begin{array}{l}\text { Quality mentoring relationships and positive ethical climates } \\
\text { relate to increased whistleblowing. }\end{array}$ \\
\hline
\end{tabular}

$\mathrm{C}=$ commentary, $\mathrm{CA}=$ content analysis, $\mathrm{E}=$ experimental, $\mathrm{M}=$ meta-analysis, $\mathrm{R}=$ review, $\mathrm{S}=$ survey. 


\section{Table 6}

Research hypotheses.

Alternative hypotheses

H1 Abusive supervision decreases the likelihood a protégé will voice a violation of firm policies and procedures.

H2 The existence of a mentoring relationship increases the likelihood a protégé will voice a violation of firm policies and procedures.

H3 The association between voicing and abusive supervision is moderated by the existence of a mentoring relationship, such that the existence of a mentoring relationship increases the likelihood of voicing a violation of firm policies and procedures.
Null hypotheses

Abusive supervision has no effect on the likelihood a protégé will voice a violation of firm policies and procedures.

The existence of a mentoring relationship has no effect on the likelihood a protégé will voice a violation of firm policies and procedures.

The association between voicing and abusive supervision is moderated by the existence of a mentoring relationship, such that the existence of a mentoring relationship has no effect on the likelihood of voicing a violation of firm policies and procedures. 


\section{Table 7}

Experimental conditions.

\begin{tabular}{lll} 
Variables & High abusive supervision & Low abusive supervision \\
\hline $\begin{array}{l}\text { High } \\
\text { mentor }\end{array}$ & $\begin{array}{l}\text { Cell 1: A mentoring relationship } \\
\text { exists; there is abusive supervision. }\end{array}$ & $\begin{array}{l}\text { Cell 2: A mentoring relationship exists; } \\
\text { there is no abusive supervision. }\end{array}$ \\
$\begin{array}{l}\text { Low } \\
\text { mentor }\end{array}$ & $\begin{array}{l}\text { Cell 3: A mentoring relationship } \\
\text { does not exist; there is abusive } \\
\text { supervision. }\end{array}$ & $\begin{array}{l}\text { Cell 4: A mentoring relationship does not } \\
\text { exist; there is not abusive supervision. }\end{array}$ \\
\end{tabular}




\section{Table 8}

Expected voicing rank by cell. ${ }^{56}$

Expected rank $^{57}$ Cell Cell description

1

Cell 2 A mentoring relationship is high; there is low abusive supervision.

2

Cell 4 A mentoring relationship is low; there is low abusive supervision.

2

Cell 1 A mentoring relationship is high; there is high abusive supervision.

Cell 3 A mentoring relationship is low; there is high abusive supervision.

56 The cell number is from Table 7.

${ }^{57}$ Highest (1) to lowest (4) expected scores on the VOICE composite measure. 
Table 9

Experimental variables.

Panel A: Model variables

\begin{tabular}{lll}
\hline Variable name & Construct & $\begin{array}{l}\text { Description } \\
\text { MENT }\end{array}$ \\
Mentor relationship & $\begin{array}{l}\text { A dichotomous variable coded } 1 \text { for a high } \\
\text { mentor relationship and } 0 \text { for a low mentor } \\
\text { relationship. }\end{array}$ \\
AuPR & Voicing intentions supervision & $\begin{array}{l}\text { A dichotomous variable coded } 1 \text { for a high } \\
\text { abusive supervisor and 0 for a low abusive } \\
\text { supervisor. }\end{array}$ \\
& $\begin{array}{l}\text { A continuous variable between } 1 \text { and } 7 \text { measured } \\
\text { as the score representing the degree to which the } \\
\text { participant is willing to voice in the workplace. } \\
\text { It is the average of } 2 \text { items. }\end{array}$ \\
\hline
\end{tabular}

Panel B: Conditioning variables

\begin{tabular}{|c|c|c|}
\hline PROACT & Proactivity & $\begin{array}{l}\text { A continuous variable between } 1 \text { and } 7 \text { measured } \\
\text { as the score representing the degree to which the } \\
\text { respondent is proactive in the workplace. It is } \\
\text { the average of the } 10 \text {-item proactivity scale } \\
\text { responses. }\end{array}$ \\
\hline OTI & $\begin{array}{l}\text { Organizational } \\
\text { turnover intentions }\end{array}$ & $\begin{array}{l}\text { A continuous variable between } 1 \text { and } 7 \text { measured } \\
\text { as the score representing the degree to which the } \\
\text { respondent would seek alternate employment } \\
\text { within } 6 \text { months. }\end{array}$ \\
\hline GENDER & Gender & A variable where 0 is female and 1 is male. \\
\hline
\end{tabular}

Panel C: Manipulation check variables

MRELATE Mentor relationship A continuous variable between 1 and 7 measured as the score representing the perception of a mentor a mentor relationship. It is the average of three items.
ABUSE
Abusive supervision
A continuous variable between 1 and 7 measured as the score representing the perception of an abusive supervisor. It is the average of three items.

Panel A includes the model variables and their descriptions. Panel B includes the conditioning variables and descriptions. Panel $\mathrm{C}$ is a description on the manipulation check variables. 


\section{Table 10}

Responses per cell in a $2 \times 2$ design.

\begin{tabular}{llll} 
Cell totals & High abusive supervision & Low abusive supervision & Total \\
\hline High mentor & 44 & 46 & 90 \\
Low mentor & 45 & 44 & 89 \\
Totals & 89 & 90 & 179 \\
\hline
\end{tabular}

Sample sizes in each of the four experimental condition. 


\section{Table 11}

Participant demographic information.

\begin{tabular}{|c|c|c|}
\hline Category & $N$ & Percentage of participants \\
\hline \multicolumn{3}{|l|}{ Age } \\
\hline $18-22$ & 87 & $48.6 \%$ \\
\hline $23-30$ & 53 & $29.6 \%$ \\
\hline $31-40$ & 33 & $18.4 \%$ \\
\hline $41-64$ & 5 & $2.8 \%$ \\
\hline $65+$ & 0 & $0.0 \%$ \\
\hline \multicolumn{3}{|l|}{ Gender } \\
\hline Male & 109 & $60.9 \%$ \\
\hline Female & 70 & $39.1 \%$ \\
\hline \multicolumn{3}{|l|}{ Highest Degree } \\
\hline High School & 22 & $12.3 \%$ \\
\hline Associate & 7 & $3.9 \%$ \\
\hline 4-year & 64 & $35.8 \%$ \\
\hline Master & 74 & $41.3 \%$ \\
\hline Doctorate & 12 & $6.7 \%$ \\
\hline \multicolumn{3}{|c|}{ Work Experience (years) } \\
\hline $0-2$ & 107 & $59.8 \%$ \\
\hline $3-5$ & 25 & $14.0 \%$ \\
\hline $6-10$ & 24 & $13.4 \%$ \\
\hline $11-14$ & 12 & $6.7 \%$ \\
\hline $15+$ & 11 & $6.1 \%$ \\
\hline
\end{tabular}




\begin{tabular}{lll}
\hline Category & $N$ & Percentage of participants \\
\hline Firm size & 11 & $6.1 \%$ \\
Big 4 & 36 & $20.1 \%$ \\
National & 33 & $18.4 \%$ \\
Regional & 15 & $8.4 \%$ \\
Local & 76 & $42.5 \%$ \\
Not Applicable & 8 & $4.5 \%$ \\
Other & & \\
Class & 73 & $40.7 \%$ \\
Undergraduate & 106 & $59.3 \%$ \\
Graduate &
\end{tabular}

Were assigned a mentor at their firm

$\begin{array}{lll}\text { Yes } & 51 & 28.5 \% \\ \text { No } & 128 & 71.5 \%\end{array}$

Developed a non-assigned mentor relationship

$\begin{array}{lll}\text { Yes } & 120 & 67.0 \% \\ \text { No } & 59 & 33.0 \%\end{array}$

Wants a mentor

$\begin{array}{lll}\text { Yes } & 149 & 83.2 \% \\ \text { No } & 30 & 16.8 \%\end{array}$

Witnessed policies and procedures violation
Yes
113
$63.1 \%$
No
66
$36.9 \%$

Demographic information responses. This table includes the number of responses for each category and the percentages. 
Table 12

Effects of demographics on response variables.

\begin{tabular}{llllll}
\hline Variable & $\begin{array}{l}\text { Assign } \\
\text { mentor }\end{array}$ & $\begin{array}{l}\text { Develop } \\
\text { mentor }\end{array}$ & Gender & $\begin{array}{l}\text { P\&P } \\
\text { violation }\end{array}$ & Want mentor \\
\hline MRELATE & -1.018 & -0.731 & 0.997 & -0.289 & 0.203 \\
ABUSE & $2.003^{*}$ & -0.115 & -0.253 & -0.635 & -.932 \\
VOICE & -1.063 & -1.041 & 1.130 & 0.011 & -0.334 \\
PROACT & -0.300 & $-2.000^{* *}$ & -0.801 & $-2.765^{* *}$ & -1.621 \\
OTI & $3.025^{* *}$ & -0.700 & -0.507 & -0.092 & -0.547 \\
\hline
\end{tabular}

${ }_{* * *}^{*}$-value $<0.100$

p-value $<0.010$

This tables shows the F-statistic results between dichotomous variables and the model and control variables. The F-statistic tests: $\mathrm{H}_{0}$ : the dichotomous demographic has no effect on the continuous variable. Assign mentor was a dichotomous variable where 0 was if the participant did not have an assigned mentor and 1 if the participant did. Develop mentor was a dichotomous variable where 0 was if the participant did not have a developed mentor and 1 if the participant did. Gender was a dichotomous variable where 0 was if the participant was female and 1 if the participant was male. P\&P violation was a dichotomous variable where 0 was if the participant had not witnessed a policies and procedures violation in the workplace and 1 if the participant had witnessed one. Want mentor was a dichotomous variable where 0 was if the participant did not want a mentor and 1 if the participant did. 


\section{Table 13}

Effects of demographics on response variables.

\begin{tabular}{llllll}
\hline Variable & Age & Class & Degree & Firm size & Work years \\
\hline MRELATE & 0.426 & 0.002 & 1.024 & $2.371^{* * *}$ & .587 \\
ABUSE & 1.400 & -0.004 & 1.086 & $2.481^{* *}$ & 0.752 \\
VOICE & 0.071 & 0.022 & 0.763 & $2.048^{*}$ & 1.016 \\
PROACT & $6.789^{* * *}$ & 0.135 & $3.886^{* * *}$ & 1.740 & $5.323^{* * *}$ \\
OTI & $2.447^{*}$ & -0.005 & 0.305 & 0.806 & 1.801
\end{tabular}

$$
\begin{aligned}
& { }^{*} \mathrm{p} \text {-value }<0.100 \\
& { }^{* *} \text { p-value }<0.050 \\
& { }^{* * *} \text { p-value }<0.010
\end{aligned}
$$

This tables shows the T-test results between categorical variables and the model and control variables. T-test statistic tests: $\mathrm{H}_{0}$ : the categorical variable has no effect on the continuous variable. Age was the participant age. Class was the program or class the participant was enrolled. Degree was the highest degree the participant earned even if it was still in progress. Firm size indicated the size of the firm the participant where the participant was employed. Work years was the amount of time the participant had worked. 


\section{Table 14}

ANOVA tests of the manipulation checks.

\begin{tabular}{lllllll}
\hline Model & Source & $\begin{array}{l}\text { Sum of } \\
\text { squares }\end{array}$ & $\begin{array}{l}\text { Degrees of } \\
\text { freedom }\end{array}$ & $\begin{array}{l}\text { Mean } \\
\text { square }\end{array}$ & F-value & $\operatorname{Pr}>$ F \\
\hline ABUSE & Model & 453.875 & 1 & 453.875 & 224.729 & $<0.001$ \\
& Error & 2.020 & 177 & 2.020 & & \\
MRELATE & Model & 4.710 & 1 & 4.710 & 2.477 & 0.117 \\
& Error & 336.509 & 177 & 336.509 & & \\
\hline
\end{tabular}

This table shows the ANOVA results of the two manipulations MENT and SUPR. The ABUSE model shows if there is a significant difference of the composite measure ABUSE at the two levels of the SUPR manipulation. The MRELATE model shows if there is a significant difference of the composite measure MRELATE at the two levels of the MENT manipulation. 
Table 15

Voicing responses and statistics.

Panel A: Responses to voicing measurements

\begin{tabular}{lll}
\hline Variable & Mean & $\begin{array}{l}\text { Standard } \\
\text { deviation }\end{array}$ \\
VOICE & 5.142 & 1.361 \\
\hline
\end{tabular}

Panel B: VOICE responses to SUPR manipulation

\begin{tabular}{llllll}
\hline & \multicolumn{2}{c}{ High abusive supervision } & & \multicolumn{2}{c}{ Low abusive supervision } \\
\cline { 1 - 3 } \cline { 5 - 6 } Variable & Mean & $\begin{array}{l}\text { Standard } \\
\text { deviation }\end{array}$ & & Mean & $\begin{array}{l}\text { Standard } \\
\text { deviation }\end{array}$ \\
VOICE & 4.904 & 1.535 & & 5.378 & 1.125 \\
\hline
\end{tabular}

Panel C: VOICE responses to MENT manipulation

\begin{tabular}{llllll}
\hline & \multicolumn{2}{c}{ High mentor relationship } & & \multicolumn{2}{c}{ Low mentor relationship } \\
\cline { 1 - 1 } \cline { 5 - 6 } Variable & Mean & $\begin{array}{l}\text { Standard } \\
\text { deviation }\end{array}$ & & Mean & $\begin{array}{l}\text { Standard } \\
\text { deviation }\end{array}$ \\
VOICE & 4.989 & 1.420 & & 5.298 & 1.287 \\
\hline
\end{tabular}

Panel A shows the mean response and standard deviation of the dependent variable VOICE.

Panel B shows the mean response and standard deviation of the dependent variable VOICE on conditions of the SUPR manipulation. Panel C shows the mean response and standard deviation of the dependent variable VOICE on conditions of the MENT manipulation. 
Table 16

The effect of MENT, SUPR, and MENT $\times$ SUPR on VOICE.

Panel A: The effect of SUPR on VOICE.

\begin{tabular}{lllllll}
\hline Variable & Source & Sum of squares & Degrees of freedom & Mean square & F-value & Pr $>$ F \\
VOICE & Model & 51.878 & 2 & 25.939 & 16.437 & $<0.000$ \\
& Intercept & 7.831 & 1 & 7.831 & 4.962 & 0.027 \\
& PROACT & 41.855 & 1 & 41.855 & 26.523 & $<0.000$ \\
& SUPR & 11.319 & 1 & 11.319 & 7.173 & 0.008 \\
\hline Panel B: The effect of MENT on VOICE & & 176 & 1.578 & & $<$ \\
\hline VOICE & Model & 42.881 & 2 & & & \\
& Error & 277.739 & 1 & 21.441 & 13.160 & $<0.000$ \\
& Intercept & 9.154 & 1 & 9.154 & 5.619 & 0.019 \\
& PROACT & 38.612 & 1 & 38.612 & 23.700 & $<0.000$ \\
& MENT & 2.321 & 176 & 2.321 & 1.425 & 0.234
\end{tabular}

Panel C: The effect of SUPR $\times$ MENT on VOICE

\begin{tabular}{|c|c|c|c|c|c|c|}
\hline \multirow[t]{7}{*}{ VOICE } & Model & 54.935 & 2 & 13.734 & 8.700 & $<0.000$ \\
\hline & Intercept & 8.775 & 1 & 8.775 & 5.588 & 0.020 \\
\hline & PROACT & 39.161 & 1 & 39.161 & 24.807 & $<0.000$ \\
\hline & SUPR & 11.486 & 1 & 11.486 & 7.276 & 0.008 \\
\hline & MENT & 2.468 & 1 & 2.468 & 1.563 & 0.380 \\
\hline & $\begin{array}{l}\text { SUPR } \times \text { M } \\
\text { ENT }\end{array}$ & 0.588 & 1 & 0.588 & 0.372 & 0.543 \\
\hline & Error & 274.682 & 174 & 1.579 & & \\
\hline
\end{tabular}

Panels A, B, and $\mathrm{C}$ present the ANCOVA results for $\mathrm{H} 1, \mathrm{H} 2$, and $\mathrm{H} 3$, respectively. 


\section{Table 17}

VOICE rank and statistics by experimental condition.

\begin{tabular}{lllll}
\hline Actual rank & Expected rank & Mean & Standard deviation & Cell description \\
\hline 1 & 1 & 5.625 & 1.035 & $\begin{array}{l}\text { A mentoring relationship is } \\
\text { high; there is low abusive } \\
\text { supervision. }\end{array}$ \\
2 & 5.141 & 1.167 & $\begin{array}{l}\text { A mentoring relationship is } \\
\text { low; there is low abusive } \\
\text { supervision. }\end{array}$ \\
3 & 4.978 & 1.434 & $\begin{array}{l}\text { A mentoring relationship is } \\
\text { low; there is high abusive } \\
\text { supervision. }\end{array}$ \\
& 4.830 & 1.642 & $\begin{array}{l}\text { A mentoring relationship is } \\
\text { high; there is high abusive } \\
\text { supervision. }\end{array}$ \\
\hline
\end{tabular}

This table shows the mean response and standard deviation of the dependent variable VOICE on each experimental condition. The expected rank column shows the a priori rank by condition. The actual rank is the high (1) to low (4) rank of the VOICE measure. 


\section{Appendix B - Figure}

\section{Figure 1}

Research model.

VOICE $=\beta_{0}+\beta_{1} S U P R+\beta_{2} M E N T+\beta_{3} S U P R \times M E N T+\beta_{4}\left[\begin{array}{c}\text { PROACT } \\ \text { GENDER } \\ \text { OTI }\end{array}\right]+\epsilon$

This figure shows research model where VOICE is the dependent variable, which is a composite measure of two-items to indicate voicing intentions. There are two independent variables: (1) SUPR and (2) MENT. SUPR is the abusive supervisor manipulation and $M E N T$ is the mentor relationship manipulation. Three conditioning variables are included: (1) PROACT, (2) GENDER, and (3) OTI, which are proactivity, gender, and organizational turnover intentions, respectively. 


\section{Appendix C - Instrument}

Dear Participant,

This survey seeks to examine your opinions concerning situations that may arise in the workplace. Your participation in this project is voluntary and your responses will be kept secure and in strict confidence. Only summary measures and conclusions will be reported. The questionnaire has 32 questions and should take approximately 15 minutes to complete.

You will be asked for your e-mail address at the end of the survey to enter in the optional drawing for eight $\$ 25$ gift cards and two $\$ 100$ gift cards; however, this data is not kept with survey responses.

Thank you for your time and participation in this research.

Sincerely,

Mackenzie M. Festa, $\mathrm{PhD}$ Candidate

Department of Accounting, College of Business and Economics

West Virginia University

mfesta@mix.wvu.edu

IRB $\# 1701406867$ 
PART ONE

Please answer the following questions.

Were you assigned a mentor when you started at your firm?

Yes

No

Have you ever developed a mentoring relationship that was not assigned?

Yes

No

Do you want a mentor?

Yes

No

Have you ever encountered a situation where you have witnessed a violation of policies or procechures at work?

Yes

No 


\section{PART ONE}

Please answer the following series of statements.

\begin{tabular}{|c|c|c|c|c|c|c|c|}
\hline & $\begin{array}{l}\text { Strongly } \\
\text { Disagree }\end{array}$ & Disagree & $\begin{array}{l}\text { Slightly } \\
\text { Disagree }\end{array}$ & Neutral & $\begin{array}{c}\text { Slightly } \\
\text { Agree }\end{array}$ & Agree & $\begin{array}{c}\text { Strongly } \\
\text { Agree }\end{array}$ \\
\hline $\begin{array}{l}\text { I am constantly } \\
\text { on the lookout } \\
\text { for new ways to } \\
\text { improve my life. }\end{array}$ & 0 & 0 & 0 & 0 & 0 & 0 & 0 \\
\hline $\begin{array}{l}\text { Wherever I have } \\
\text { been, I have } \\
\text { been a powerful } \\
\text { force for } \\
\text { constructive } \\
\text { change. }\end{array}$ & 0 & 0 & 0 & 0 & 0 & 0 & 0 \\
\hline $\begin{array}{l}\text { Nothing is more } \\
\text { exciting than } \\
\text { seeing my ideas } \\
\text { turn into reality. }\end{array}$ & 0 & 0 & 0 & 0 & 0 & $\bigcirc$ & 0 \\
\hline $\begin{array}{l}\text { If I see } \\
\text { something I } \\
\text { don't like, I fix } \\
\text { it. }\end{array}$ & 0 & 0 & 0 & 0 & 0 & 0 & 0 \\
\hline \multirow[t]{2}{*}{$\begin{array}{l}\text { No matter what } \\
\text { the odds, if I } \\
\text { believe in } \\
\text { something I will } \\
\text { make it happen. }\end{array}$} & 0 & 0 & 0 & 0 & 0 & 0 & 0 \\
\hline & $\begin{array}{l}\text { Strongly } \\
\text { Disagree }\end{array}$ & Disagree & $\begin{array}{l}\text { Slightly } \\
\text { Disagree }\end{array}$ & Neutral & $\begin{array}{c}\text { Slightly } \\
\text { Agree }\end{array}$ & Agree & $\begin{array}{l}\text { Strongly } \\
\text { Agree }\end{array}$ \\
\hline $\begin{array}{l}\text { Ilove being a } \\
\text { champion for my } \\
\text { own ideas, even } \\
\text { against others' } \\
\text { opposition. }\end{array}$ & 0 & 0 & 0 & 0 & 0 & 0 & 0 \\
\hline $\begin{array}{l}\text { I excel at } \\
\text { identifying } \\
\text { opportunities. }\end{array}$ & 0 & 0 & 0 & 0 & 0 & 0 & 0 \\
\hline $\begin{array}{l}\text { I am always } \\
\text { looking for } \\
\text { better ways to do } \\
\text { things. }\end{array}$ & 0 & 0 & 0 & 0 & 0 & 0 & 0 \\
\hline $\begin{array}{l}\text { If I believe in an } \\
\text { idea, no obstacle } \\
\text { will prevent me } \\
\text { from making it } \\
\text { happen. }\end{array}$ & 0 & 0 & 0 & 0 & 0 & 0 & 0 \\
\hline $\begin{array}{l}\text { I can spot a good } \\
\text { opportunity long } \\
\text { before others } \\
\text { can. }\end{array}$ & 0 & 0 & 0 & 0 & 0 & 0 & 0 \\
\hline
\end{tabular}




\section{The following vignette was used to represent high abusive supervision and a low mentoring relationship: ${ }^{58}$}

\section{PART TWO}

Please carefully read the following scenario and answer the questions based on the scenario.

The Accounting Firm

You work for a large national firm in a major metropolitan city on the east coast. This is your first job since earning your degree. Your firm does not have a formal mentoring system, but you receive mentoring guidance from a supervisor in another division of your firm who went to your university. You get together after work at a variety of social gatherings and share the same attitude, values, and behaviors. While you do not work directly together, you have become friends.

You and an associate have recently been assigned to the same client as members of a small team, which is responsible for highly confidential client analysis related to proposed and actual mergers and acquisitions. Your firm has a strict confidentiality policy.

You have noted instances where you observed your colleague exposing client information in a public setting. Initially, you confronted your colleague about the importance confidentiality directly. However, a couple of days later, information was compromised again.

Fearing the exposure could become public and jeopardize the client's plans for a merger, you meet with your direct supervisor. Your supervisor has been with the firm for five years and has high expectations for subordinates to perform tasks in the best interest of the firm. You discuss how this places the firm's reputation and integrity at risk.

Your supervisor has a reputation of frequently making negative comments to the team. During your conversation about the possible exposure, with the door to the office open your supervisor becomes visibly upset and yells at you allowing your team to hear. Your supervisor slams the door shut and severely criticizes you saying how it's not your place to try to lead the team and that the expectation in this firm is that supervisors run their teams without interference from associates. It is made clear that behavior like this in the future will not be tolerated and could lead to termination. You attempt to speak, but you are interrupted and told to go back to work.

\footnotetext{
${ }^{58}$ Language mentioning the type of vignette was not included in the instrument. It is presented for the informational purposes of the reader.
} 


\section{The following vignette was used to represent low abusive supervision and a low mentoring relationship: ${ }^{59}$}

\section{PART TWO}

Please carefully read the following scenario and answer the questions based on the scenario.

\section{The Accounting Firm}

You work for a large national firm in a major metropolitan city on the east coast. This is your first job since earning your degree. Your firm does not have a formal mentoring system, but you receive mentoring guidance from a supervisor in another division of your firm who went to your university. You get together after work at a variety of social gatherings and share the same attitude, values, and behaviors. While you do not work directly together, you have become friends.

You and an associate have recently been assigned to the same client as members of a small team, which is responsible for highly confidential client analysis related to proposed and actual mergers and acquisitions. Your firm has a strict confidentiality policy.

You have noted instances where you observed your colleague exposing client information in a public setting. Initially, you confronted your colleague about the importance confidentiality directly. However, a couple of days later, information was compromised again.

Fearing the exposure could become public and jeopardize the client's plans for a merger, you meet with your direct supervisor. Your supervisor has been with the firm for five years and has high expectations for subordinates to perform tasks in the best interest of the firm. You discuss how this places the firm's reputation and integrity at risk.

Your supervisor has a reputation of frequently making positive comments to the team. During your conversation about the possible exposure, they immediately become concerned and listen to you closely. You are complimented on your handling of the situation and it's made clear that your actions should be copied by others at the firm.

\footnotetext{
${ }^{59}$ Language mentioning the type of vignette was not included in the instrument. It is presented for the informational purposes of the reader.
} 


\section{The following vignette was used to represent high abusive supervision and a high mentoring relationship: ${ }^{60}$}

\section{PART TWO}

Please carefully read the following scenario. Afterwards, answer the questions based on the scenario.

The Accounting Firm

You work for a large national firm in a major metropolitan city on the east coast. This is your first job since earning your degree. Your firm does not have a formal mentoring system, but you receive mentoring guidance from a supervisor in another division of your firm who went to your university. You get together after work at a variety of social gatherings, which have been very helpful in teaching you the "ins and outs" of the firm. While you do not work directly with one another you routinely interact and discuss strategies to help increase your visibility in the firm and make the best decisions about sensitive issues.

You and an associate have recently been assigned to the same client as members of a small team, which is responsible for highly confidential client analysis related to proposed and actual mergers and acquisitions. Your firm has a strict confidentiality policy.

You have noted instances where you observed your colleague exposing client information in a public setting. Initially, you confronted your colleague about the importance confidentiality directly. However, a couple of days later, information was compromised again.

Fearing the exposure could become public and jeopardize the client's plans for a merger, you meet with your direct supervisor. Your supervisor has been with the firm for five years and has high expectations for subordinates to perform tasks in the best interest of the firm. You discuss how this places the firm's reputation and integrity at risk.

Your supervisor has a reputation of frequently making negative comments to the team. During your conversation about the possible exposure, with the door to the office open your supervisor becomes visibly upset and yells at you allowing your team to hear. Your supervisor slams the door shut and severely criticizes you saying how it's not your place to try to lead the team and that the expectation in this firm is that supervisors run their teams without interference from associates. It is made clear that behavior like this in the future will not be tolerated and could lead to termination. You attempt to speak, but you are interrupted and told to go back to work.

\footnotetext{
${ }^{60}$ Language mentioning the type of vignette was not included in the instrument. It is presented for the informational purposes of the reader.
} 


\section{The following vignette was used to represent low abusive supervision and a high mentoring relationship: ${ }^{61}$}

\section{PART TWO}

Please carefully read the following scenario and answer the questions based on the scenario.

The Accounting Firm

You work for a large national firm in a major metropolitan city on the east coast. This is your first job since earning your degree. Your firm does not have a formal mentoring system, but you receive mentoring guidance from a supervisor in another division of your firm who went to your university. You get together after work at a variety of social gatherings, which have been very helpful in teaching you the "ins and outs" of the firm. While you do not work directly with one another you routinely interact and discuss strategies to help increase your visibility in the firm and make the best decisions about sensitive issues.

You and an associate have recently been assigned to the same client as members of a small team, which is responsible for highly confidential client analysis related to proposed and actual mergers and acquisitions. Your firm has a strict confidentiality policy.

You have noted instances where you observed your colleague exposing client information in a public setting. Initially, you confronted your colleague about the importance confidentiality directly. However, a couple of days later, information was compromised again.

Fearing the exposure could become public and jeopardize the client's plans for a merger, you meet with your direct supervisor. Your supervisor has been with the firm for five years and has high expectations for subordinates to perform tasks in the best interest of the firm. You discuss how this places the firm's reputation and integrity at risk.

Your supervisor has a reputation of frequently making positive comments to the team. During your conversation about the possible exposure, they immediately become concerned and listen to you closely. You are complimented on your handling of the situation and it's made clear that your actions should be copied by others at the firm.

\footnotetext{
${ }^{61}$ Language mentioning the type of vignette was not included in the instrument. It is presented for the informational purposes of the reader.
} 
Based on the scenario above please answer the following questions.

\begin{tabular}{|c|c|c|c|c|c|c|c|}
\hline & $\begin{array}{l}\text { Strongly } \\
\text { Disagree }\end{array}$ & Disagree & $\begin{array}{c}\text { Slightly } \\
\text { Disagree }\end{array}$ & Neutral & $\begin{array}{l}\text { Slightly } \\
\text { Agree }\end{array}$ & Agree & $\begin{array}{l}\text { Strongly } \\
\text { Agree }\end{array}$ \\
\hline $\begin{array}{l}\text { Your supervisor is } \\
\text { rude to you. }\end{array}$ & 0 & 0 & 0 & 0 & 0 & 0 & 0 \\
\hline $\begin{array}{l}\text { Your mentor uses } \\
\text { influence to } \\
\text { support your } \\
\text { advancement in } \\
\text { the firm. }\end{array}$ & 0 & 0 & 0 & 0 & 0 & 0 & 0 \\
\hline $\begin{array}{l}\text { Your mentor gives } \\
\text { you advice on } \\
\text { how to attain } \\
\text { recognition in the } \\
\text { firm. }\end{array}$ & 0 & 0 & 0 & 0 & 0 & 0 & 0 \\
\hline $\begin{array}{l}\text { You would seek } \\
\text { alternate } \\
\text { employment } \\
\text { within six months. }\end{array}$ & 0 & 0 & 0 & 0 & 0 & 0 & 0 \\
\hline \multirow[t]{2}{*}{$\begin{array}{l}\text { Your supervisor } \\
\text { puts you down in } \\
\text { front of others. }\end{array}$} & 0 & 0 & 0 & 0 & 0 & 0 & 0 \\
\hline & $\begin{array}{l}\text { Strongly } \\
\text { Disagree }\end{array}$ & Disagree & $\begin{array}{c}\text { Slightly } \\
\text { Disagree }\end{array}$ & Neutral & $\begin{array}{l}\text { Slightly } \\
\text { Agree }\end{array}$ & Agree & $\begin{array}{c}\text { Strongly } \\
\text { Agree }\end{array}$ \\
\hline $\begin{array}{l}\text { Your supervisor } \\
\text { ridicules you. }\end{array}$ & 0 & 0 & 0 & 0 & 0 & 0 & 0 \\
\hline $\begin{array}{l}\text { You are } \\
\text { comfortable } \\
\text { speaking up about } \\
\text { your supervisor's } \\
\text { actions to their } \\
\text { superior. }\end{array}$ & 0 & 0 & 0 & 0 & 0 & 0 & 0 \\
\hline $\begin{array}{l}\text { Your mentor } \\
\text { suggests specific } \\
\text { strategies for } \\
\text { achieving your } \\
\text { career aspirations. }\end{array}$ & 0 & 0 & 0 & 0 & 0 & 0 & 0 \\
\hline $\begin{array}{l}\text { You are willing to } \\
\text { speak up about } \\
\text { your supervisor's } \\
\text { actions to their } \\
\text { superior. }\end{array}$ & 0 & 0 & 0 & 0 & 0 & 0 & 0 \\
\hline
\end{tabular}


PART TWO

Based on the scenario you just read, answer the following questions.

Was your colleague male or female?

Male

Female

Was your supervisor male or female?

Male

Female

Was your mentor male or female?

Male

Female 


\section{PART THREE}

Please answer the following questions.

What is your idea of a mentor?

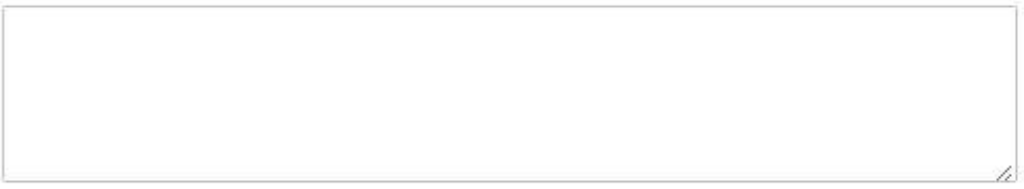

What is your gender?

Male

Female

What is your age?

18-22

23-30

$31-40$

41-64

$65+$ 
What is the highest degree you have attained? (Even if in progress).

High School Degree or Equivalent

Associate Degree

4-year Degree

Master Degree

Doctoral Degree

How many years of professional work experience do you have?

$0-2$

$3-5$

$6-10$

$11-14$

$15+$ 
If applicable, what is the size of your firm?

\begin{tabular}{|l|}
\hline Big 4 \\
\hline National \\
\hline Regional \\
\hline Local \\
\hline
\end{tabular}

Not Applicable

Other, please describe.

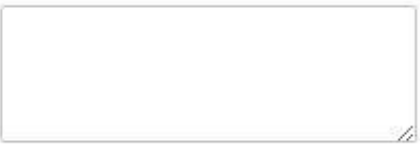

Please discuss any thoughts you may have about this survey.

If you would like to be entered into the drawing for eight $\$ 25$ gitt cards and two $\$ 100$ gitt cards, please enter your email. All responses are kept strictly confidential.

Email 